\title{
Climatology and ablation at the South Greenland ice sheet margin from automatic weather station observations
}

D. van As ${ }^{1}$, C. E. Bøggild ${ }^{2,1}$, S. Nielsen ${ }^{1}$, A. P. Ahlstrøm ${ }^{1}$, R. S. Fausto ${ }^{1,3}$, S. Podlech ${ }^{1, *}$, and M. L. Andersen ${ }^{1,3}$

${ }^{1}$ Geological Survey of Denmark and Greenland, Copenhagen, Denmark

${ }^{2}$ The University Centre in Svalbard, Longyearbyen, Norway

${ }^{3}$ Centre for Ice and Climate, University of Copenhagen, Copenhagen, Denmark *now at: Esbjerg Institute of Technology, Aalborg University, Esbjerg, Denmark

Received: 11 December 2008 - Accepted: 22 December 2008 - Published: 26 January 2009 Correspondence to: D. van As, dva @geus.dk

Published by Copernicus Publications on behalf of the European Geosciences Union.

\section{South Greenland climatology and ablation \\ D. van As et al.}

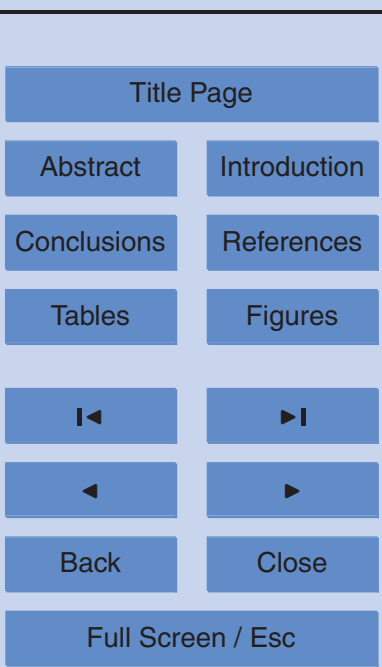

Printer-friendly Version

Interactive Discussion 


\section{Abstract}

We describe the climatology from a meteorological dataset acquired from automatic weather station observations done in the ablation zone of the Greenland Ice Sheet between 2001 and 2007. Stations were placed in three regions below the polar circle: 5 on the southern tip of the ice sheet, on a calving glacier in the Nuuk fjord, and on the south-eastern ice margin near Tasiilaq. The yearly cycles in temperature, relative humidity and wind speed reveal the largest variability in wintertime, causing annual values to depend largely on winter values. Adding to wintertime variability are extremely strong and cold katabatic wind events in the southeast ("piteraqs"). During summer no pronounced daily cycle in near-surface atmospheric parameters is recorded in the three regions, in spite of a large cycle in solar radiation, dominantly regulating surface melt. Net ablation is largest at the southernmost station due to low surface albedo, and can be up to six metres per year, but is highly sensitive to the timing of the start of the ice ablation season. Illustrative of this is that similar ablation amounts are found in the

15 Nuuk fjord region where little or no snow accumulates in winter.

\section{Introduction}

The polar regions are currently subject to profound change. Telltale signs hereof are the rapid reduction in arctic sea-ice cover (Comiso et al., 2008), the retreat of major Greenlandic outlet glaciers (Joughin et al., 2008), and the disintegration of ice shelves on the Antarctic Peninsula (Cook et al., 2005). For obvious reasons, more and more attention is turning to the state of the Greenlandic Ice Sheet (GrIS) with its potential to contribute to global sea level rise by about seven meters.

Changes in ice dynamics are governing mass balance changes of the GrIS. Recent studies revealed a speed-up of major outlet glaciers (Stearns and Hamilton, 2007), and a northward progression of this acceleration (Rignot and Kanagaratnam, 2006). Surface melt water run-off has been proven to have a considerable impact on ice dy-

3, 117-158, 2009

\section{South Greenland climatology and ablation \\ D. van As et al.}

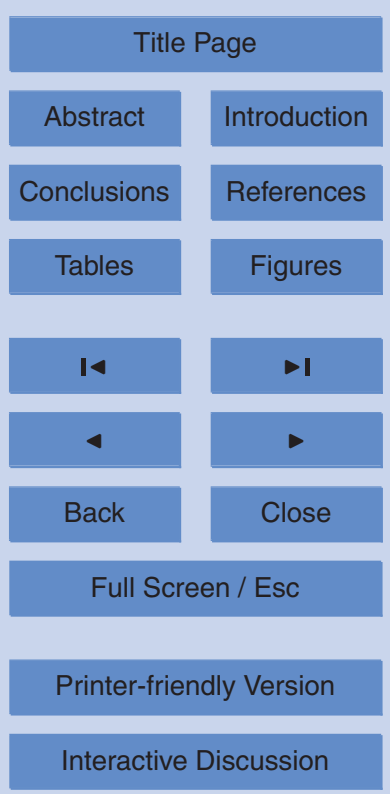

Interactive Discussion 
namics through basal lubrication (Parizek and Alley, 2004), the effect of which is largest on day-to-day timescales (Van de Wal et al., 2008). With run-off both directly and indirectly influencing the GrIS mass budget it is vital to quantify surface melt.

Satellite observations are ideal to detect surface melt over large areas. For instance,

5 Wang et al. (2007) showed that most of the GrIS surface can experience melt, and Mote (2007) showed that the surface area of the GrIS affected by melt was larger in 2007 than it has been since 1973. The best way to obtain surface melt amounts and spatial variability therein is to run a regional climate model over Greenland, resolving the narrow ablation zone and the thin atmospheric boundary layer, and incorporating 10 the full surface energy balance (SEB), a sub-surface snow model, and ideally a snow drift parameterization (Box et al., 2006; Fettweis et al., 2006; Bougamont et al., 2007). As a rule all surface mass balance calculations, ranging from complex atmospheric model output to positive degree-day estimates, need validation or tuning by in-situ measurement where possible (e.g. Box and Rinke, 2003).

15 AWSs have provided a wealth of in-situ climatological information across Greenland. Twelve years (1987 to 1999) of observations at Summit provided an accurate series of temperatures, even resolving the aftermath of the Mount Pinatubo eruption in 1991 (Shuman et al., 2001). Box and Steffen (2001) determined surface mass loss through sublimation in the interior of the GrIS. Hanna et al. (2008) used weather station records to show that South Greenland temperatures in recent years have not been higher in decades, positively impacting the melt water run-off.

A better coverage of AWSs on the GrIS therefore implies higher accuracy in surface mass balance estimates. Current AWS coverage on the ice sheet is fair. In 1995 the Cooperative Institute for Research in Environmental Sciences (CIRES) started the 25 Greenland Climate Network (GC-Net), currently consisting of $\sim 15$ stations, the majority of which are in the accumulation zone. The Institute for Marine and Atmospheric Research in Utrecht (IMAU) maintains an AWS transect in the ablation zone in the Kangerlussuaq region initiated in 1996 (Van de Wal et al., 2005). From 2007 onwards, the Geological Survey of Denmark and Greenland (GEUS) has started to add seven

\section{South Greenland climatology and ablation \\ D. van As et al.}

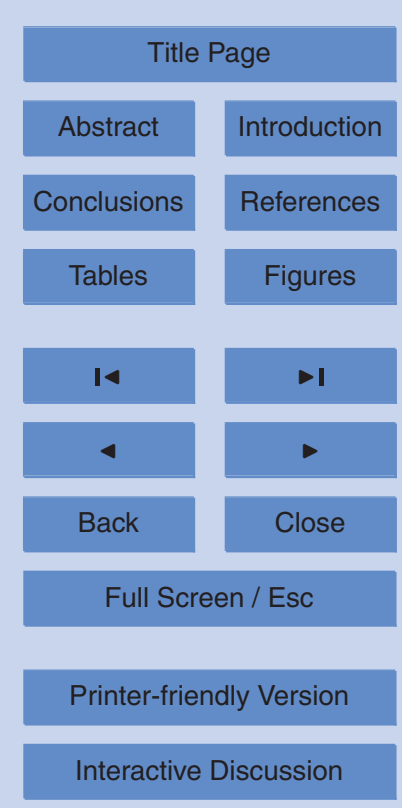


transects in the ablation zone around the GrIS (http://www.promice.org). In addition, the Danish Meteorological Institute (DMI) has 40+ land stations around the ice sheet with climate records dating back to 1873 (Box, 2002).

Between 2001 and 2007 GEUS made a successful attempt to monitor the climatol5 ogy and melt at the ice sheet margin in South Greenland, where the ice sheet has been known to be dynamically thinning for some time (Krabill et al., 1999). Six AWSs were placed within the Ice Monitoring (IceMon) project, distributed over the Qaqortoq, Nuuk, and Tasiilaq regions (Fig. 1). Podlech et al. (2004) used the Qaqortoq data in an analysis of the recent retreat and thinning of Sermilik Bræ, a South Greenland outlet glacier.

This paper aims to contribute to the knowledge of melt in the GrIS margin, where very few in-situ observations have been performed. We present the climatology of the south GrIS using AWS data, both focusing on atmospheric conditions and melt, supported by data from CIRES and DMI. In the next section we will discuss the observations, the corrections that are needed for AWS measurements on the ice, and the method for calculating the surface energy balance. Thereafter we will present observational records of meteorological parameters, the summertime surface energy fluxes, and net ablation estimates and inaccuracies therein for the three southerly regions. At the end, a short summary is given.

\section{Methods}

\subsection{Observations}

This paper deals with AWS observations on the southern part of the GrIS (Fig. 1). The three stations central in this study are named "St71", located on the southern tip of the ice sheet near a settlement named Qassimiut, "Nuuk2", located in the higher regions of the Narsap Sermia glacier in the southwest, and "Tas1", placed on a southward protruding lobe of the inland ice almost $60 \mathrm{~km}$ west of Tasiilaq (Fig. 1). Metadata on the

\section{South Greenland climatology and ablation \\ D. van As et al.}

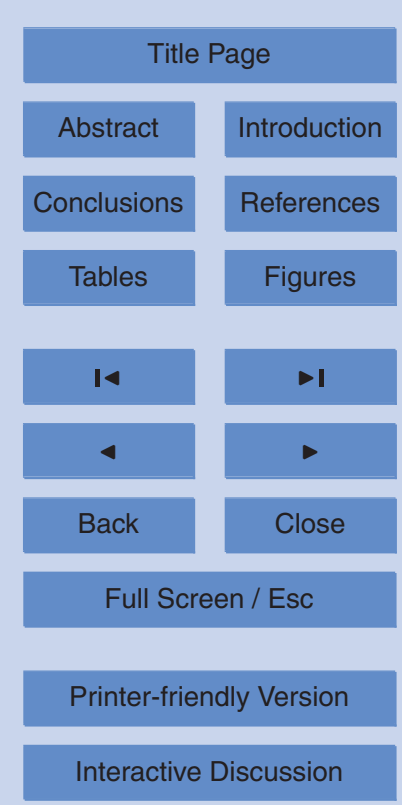

Interactive Discussion 
AWSs are listed in Table 1. In each region a second station was placed to be able to determine along-slope gradients. St71 is the lower of the two AWSs on the Qassimiut Lobe; Nuuk2 and Tas1 are the upper AWSs in the two-station transects, but still well below the equilibrium line altitude. In spite of making use of well-recognized and 5 reliable sensors, the harsh circumstances in the GrIS margin cause great difficulties in obtaining continuous data sets. For instance, the second AWS in the southwest (Nuuk1) was placed in a crevassed area of the fast-flowing Narsap Sermia glacier and was not found upon return. Wind damage to the second south-eastern AWS (Tas3) reduced the amount of useful data from this station. Its predecessor (Tas2) presum10 ably collapsed during a piteraq event (powerful, cold katabatic winds occurring on the southeast coast). Other problems involve sensors and loggers to be submerged in wet snow in spring, high station tilt due to irregular surface melt in summer, and freezing and thawing cycles for temperatures around the freezing point.

The skeleton of the IceMon AWSs consisted of an aluminium tripod with a lower 15 and upper horizontal boom attached. The stations were not drilled into the ice, but were sinking with the ablating ice surface, allowing a fixed sensor height during the ice melt season. Small wooden boards with long bolts running through were mounted underneath the feet of the tripods to keep them fixed, without melting into the ice by solar heating. The AWSs measured air temperature $(T)$, relative humidity $(\mathrm{RH})$, wind speed $(W S)$ and direction, incoming and reflected shortwave radiation $\left(S R_{\text {in \& out }}\right)$, and incoming longwave radiation $\left(L R_{\text {in }}\right)$ by the sensors listed in Table 2 . Measurements were taken every full hour; data were transmitted four times per day in summer only. Temperature, humidity, and wind sensors were mounted on the upper boom at 2.5-3 $\mathrm{m}$ above the feet of the tripod; the radiation instruments were mounted on the lower boom at $1-1.5 \mathrm{~m}$. The Eppley longwave radiation instrument at Tas 1 did not record sensor housing temperature, needed for $L R_{\text {in }}$ calculation. Instead we used air temperature, by which we may underestimate $L R_{\text {in }}$ for situations with high solar radiation and wind speeds below about $3 \mathrm{~ms}^{-1}$.

Ice ablation was measured using an experimental set-up in which a pressure trans-

\section{South Greenland climatology and ablation \\ D. van As et al.}

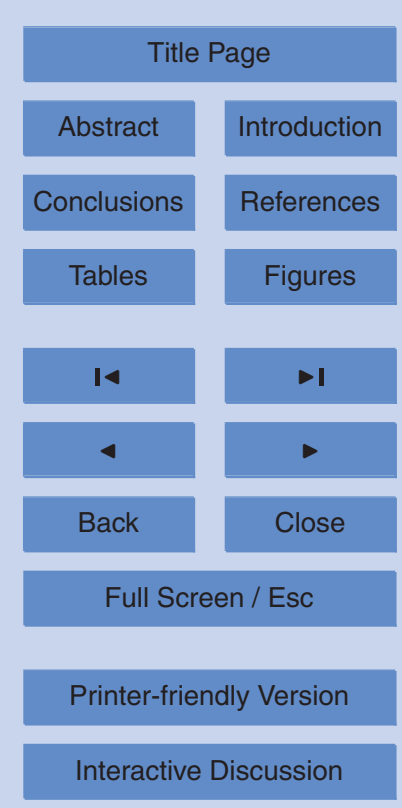


ducer was placed at the bottom of a liquid-filled hose drilled $30-40 \mathrm{~m}$ into the ice (Bøggild et al., 2004). Ablation can be deduced from the changes in the vertical liquid column pressing on the transducer. The major advantage of this system is that it can be left to measure for years on end, whereas a stake set-up with sonic rangers needs to be 5 redrilled regularly in high-melt regions. In combination with a sonic ranger mounted on the AWS measuring snow accumulation/instrument height this provides a year-round record of surface height variability. Although GEUS has successfully deployed the ablation system for instance on the ice in the Melville Bay area, the observations at St71, Nuuk2, and Tas1 were hampered by developmental problems. Due to the uncertain10 ties that exist in the output of the ablation systems obtained at St71, Nuuk2, and Tas1 we consider these data unsuitable for validation of the mass balance calculations presented in the results section. In addition to this, most sonic rangers did not survive the winter or gave questionable results due to damage by rapid succession of thawing and freezing of moisture on the sensor membrane, leaving us with few direct mass-balance measurements.

Finally, the AWSs were equipped with sensors tracking tilt and rotation, which is a necessary addition when irregular melt provides a constantly changing surface for the stations to rest on. These data give insight into the state of the AWS, and are crucial in correcting $S R_{\text {in }}$ under clear-sky conditions.

Unfortunately, data gaps are common for measurements in the ablation zone of the GrIS, even for a robust measurement as temperature (Fig. 2), which is illustrative of the tough environment the AWSs are placed in.

\subsection{Data corrections}

We performed several data corrections/recalculations, such as calculating wind direc25 tion relative to the true north (magnetic declinations for locations and time periods discussed here vary between $27-32^{\circ} \mathrm{W}$ ), and removing the temperature-dependence of the sonic ranger output. Relative humidity (measured with respect to water) was corrected at sub-freezing temperatures by recalculating it to values with respect to ice,

\section{South Greenland climatology and ablation \\ D. van As et al.}

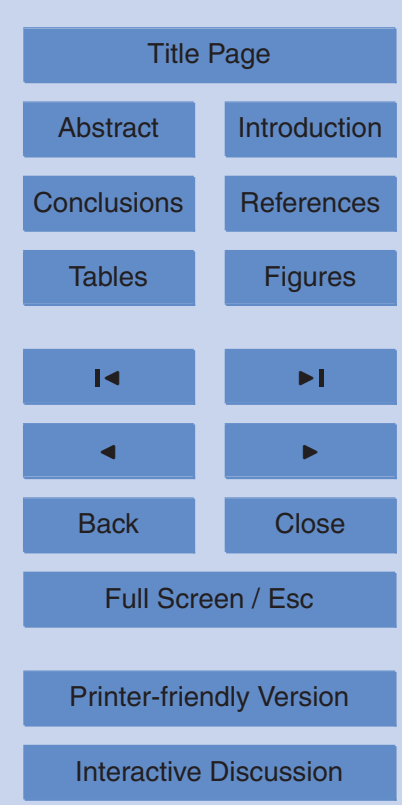


and scaling it to fit a $0-100 \%$ range, as proposed by Anderson (1994).

Most important is the correction of the shortwave radiation input, as this is the dominant parameter when it comes to ablation in Greenland (Van de Wal et al., 2005). For the type of sensors used in this study, the double-domed Kipp \& Zonen CM7, it is cru5 cial that it is placed horizontally due to its sensitivity to beam direction (Van den Broeke et al., 2004). In the regions and years described in this paper on occasion very high tilt values were recorded ( $\max .11^{\circ}$ for St71, $16^{\circ}$ for Nuuk2, and $3^{\circ}$ for Tas 1 ), which calls for a thorough correction procedure.

$S R_{\text {in }}$ is corrected assuming that the radiation is composed of a diffuse and direct 10 beam part, of which only the direct component requires adjustment for sensor tilt. Thus for a horizontal sensor, the direct component equals $S R_{\text {in }}$ reduced by its diffuse fraction $(D F)$. For a tilted sensor, $S R_{\text {in }}$ is determined from the measured value $\left(S R_{\text {in,measured }}\right)$ following

$S R_{\text {in }}=D F \times S R_{\text {in }}+C \times\left(S R_{\text {in, measured }}-D F \times S R_{\text {in }}\right)$,

15 where $C$ is the direct beam correction factor using a complex but straightforward algebraic transformation. From this we get:

$S R_{\text {in }}=S R_{\text {in, measured }} \times \frac{C}{1-D F+C \times D F}$.

$D F$ is estimated to range from 0.2 for clear-skies to 1 for overcast conditions (Harrison et al., 2008), assuming a linear dependency on the cloud fraction. Cloud fraction 20 is approximated from the dependence of near-surface temperature on $L R_{\text {in }}$. After determining the relationships between $L R_{\text {in }}$ and near-surface $T$ for both clear and cloudy conditions at each site (Van As et al., 2005), linear interpolation gives an estimate of the cloud fraction for certain pairs of $L R_{\text {in }}$ and $T$ measurements.

Finally, both $S R_{\text {in }}$ and $S R_{\text {out }}$ values were hand-checked for spikes. After applying 25 this correction method to $S R$ for tilt, large errors may still occur. The sensitivity of our calculations to $S R$ inaccuracy will be investigated below.

\section{South Greenland climatology and ablation \\ D. van As et al.}

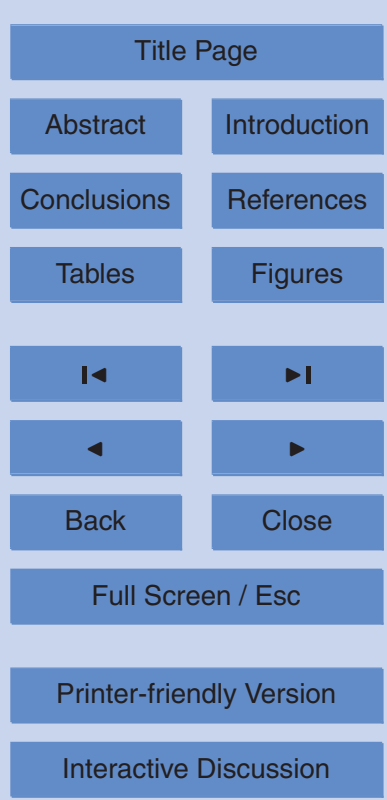




\subsection{Surface energy balance calculations}

In this paper we present net ablation estimates, calculated by running a surface energy balance model over an ice surface. The SEB model shows great resemblance to the model elaborately described by Van As et al. (2005), who calculated the surface energy 5 fluxes over snow for the interior of Antarctica.

The surface energy balance is defined as:

$S R_{\text {net }}+L R_{\text {net }}+S H+L H+S S H=M$,

where $S R_{\text {net }}$ and $L R_{\text {net }}$ are the net short- and longwave radiative fluxes, and $S H, L H$ and $S S H$ are the sensible, latent and sub-surface heat fluxes, respectively. The fluxes are defined positive when adding energy to the surface. Using measurements from our AWSs, we are able to calculate the full energy budget, providing we iterate to find the surface temperature $\left(T_{s}\right)$ for which all left-hand side terms are balanced. $M$ is the energy used for surface melt when the left-hand side fluxes cannot be balanced, i.e. when the calculated surface temperature is limited by the melting point.

15 The radiative fluxes are the sum of their (positive) incoming and (negative) outgoing components. $S R_{\text {in }}, S R_{\text {out }}$, and $L R_{\text {in }}$ were measured, and the longwave radiation emitted by the surface $\left(L R_{\text {out }}\right)$ is determined assuming black-body radiative properties using surface temperature. Although we calculate the surface energy balance over ice, which potentially allows for considerable shortwave radiation penetration, we do not take subsurface $S R$ absorption into account, thereby overestimating surface heating/ablation and ignoring sub-surface heating/melt. We argue here that the consequences for net ablation at the end of the summer will be minor, since total ablation is in the order of meters, while most of the $S R$ is absorbed in the upper few centimetres of ice. Van den Broeke et al. (2008b) demonstrate for AWS observations in Southwest Greenland that $S R$ penetration is capable of producing considerable amount of sub-surface melt, but that the total ice ablation at the end of the summer is not heavily affected.

\section{South Greenland climatology and ablation \\ D. van As et al.}

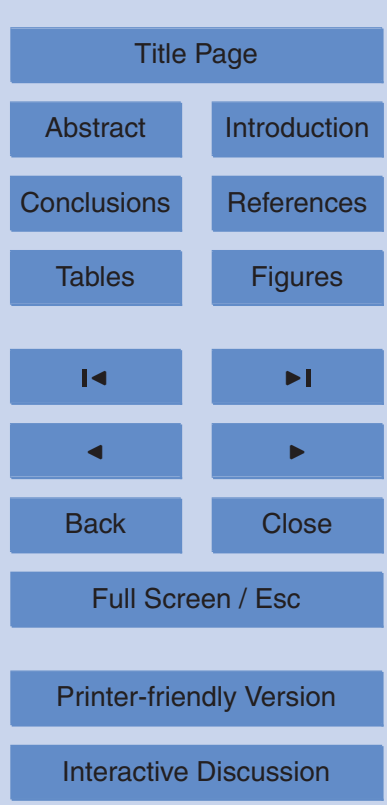


$S H$ and $L H$ are calculated using the bulk method, assuming Monin-Obukhov similarity. Doing so allows the turbulent heat fluxes to be approximated by:

$S H=\rho c_{p} k^{2} \frac{W S}{\left(\ln \left(\frac{z_{m}}{z_{0 \mathrm{~m}}}\right)-\psi_{\mathrm{m}}\right)} \frac{\left(T-T_{S}\right)}{\left(\ln \left(\frac{z_{T}}{z_{0 T}}\right)-\psi_{T}\right)}$,

and

$5 \quad L H=\rho L_{s / v} \kappa^{2} \frac{W S}{\left(\ln \left(\frac{z_{\mathrm{m}}}{z_{0 \mathrm{~m}}}\right)-\psi_{\mathrm{m}}\right)} \frac{\left(q-q_{s}\right)}{\left(\ln \left(\frac{z_{q}}{z_{0 q}}\right)-\psi_{q}\right)}$.

Here $\rho$ is air density, $c_{p}=1005 \mathrm{~J} \mathrm{~K}^{-1} \mathrm{~kg}^{-1}$ is the specific heat of dry air at constant pressure, $L_{s}=2.83 \times 10^{6} \mathrm{~J} \mathrm{~kg}^{-1}$ is the latent heat of sublimation, $L_{v}=2.50 \times 10^{6} \mathrm{~J} \mathrm{~kg}^{-1}$ is the latent heat of vaporization, $k=0.4$ is Von Kármán's constant, $q_{(s)}$ is specific humidity (at the surface), $z_{\mathrm{m} / T / q}$ is the measurement height of $W S, T$, and $q, z_{0 \mathrm{~m} / T / q}$ is the surface roughness length for momentum/heat/moisture, and $\psi_{\mathrm{m} / T / q}$ is the stability correction function for momentum/heat/moisture. These equations use near-surface gradients in wind speed, temperature, and specific humidity, which can be deduced from the AWS records, using the surface as the lower level. Air at the surface is saturated, thus $q_{s}$ can be calculated from $T_{s}$. We utilize stability-correction functions by Holtslag and De Bruin (1988) for stable stratification and by Paulson (1970) for unstable stratification. The surface roughness length for momentum is chosen to have a constant value of $1 \times 10^{-2} \mathrm{~m}$, which is a common value for ice surfaces shown in a listing by Brock et al. (2006). The surface roughnesses for heat and moisture were calculated in accordance with Smeets and Van den Broeke (2008a), and have identical magnitudes. Air density was determined from air pressure, assuming constant values of 980,920 , and $950 \mathrm{hPa}$ for St71, Nuuk2, and Tas1, respectively. These pressures were chosen based on mean summertime values obtained by PROMICE AWSs on the same locations in 2007 and 2008.

\section{South Greenland climatology and ablation \\ D. van As et al.}

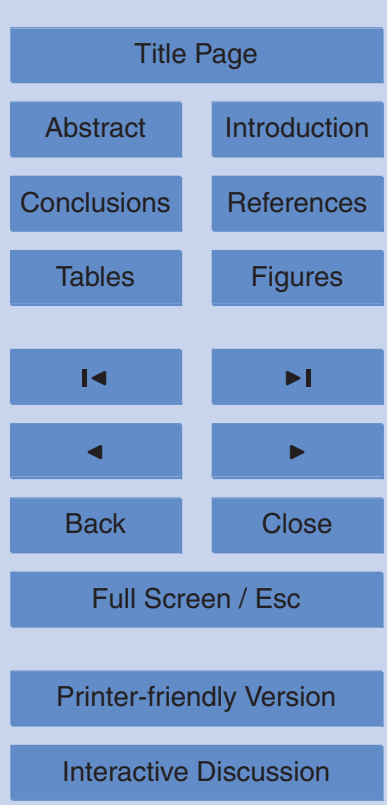

(1) 
The latent heat flux also contributes to the mass balance of a freezing surface through sublimation and deposition. However, for a wet, melting surface latent heat is used for evaporation and condensation, therewith only affecting the amount of runoff, not the ice mass. Since less energy is needed for evaporation than for sublimation 5 (a 13\% difference) the role of the latent heat flux is reduced over a melting surface.

The sub-surface heat flux is calculated up to $20 \mathrm{~m}$ depth using a grid spacing of $5 \times 10^{-2} \mathrm{~m}$. Ice temperature evolution depends on the ice temperature gradient, the density-dependent effective conductivity of snow and ice, and the temperaturedependent specific heat of snow and ice. Here, ice density is assumed constant at 10 $900 \mathrm{~kg} \mathrm{~m}^{-3}$ with an effective conductivity of $2.2 \mathrm{WK}^{-1} \mathrm{~m}^{-1}$. The initial temperature profile was set to $0^{\circ} \mathrm{C}$.

Sensitivity of the model results to input inaccuracies or false assumptions will be tested after presenting the results.

\section{Results}

\section{3.1 Temperature, humidity, and wind}

Figure 2 shows monthly-mean $T$ data with standard deviations at all six AWSs for the full operational periods. A clear yearly cycle is recorded for all locations. Near-surface temperatures are strongly regulated by surface temperatures, causing values at most a few degrees above melting point and low variability in summer when the ice surface is melting. For the low-lying St71 site ( $300 \mathrm{~m}$ above sea level) positive temperatures occur for five to six months. At the other two locations this period is shorter (three to four months) due to higher latitude and elevation, and at the farther inland Nuuk2 station also due to lower exposure to heat advection by the large-scale atmospheric circulation over the ocean.

25 In wintertime surface temperatures are well below freezing and thus free to follow atmospheric changes, explaining the larger near-surface $T$ variability. Lowest tempera-

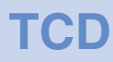

3, 117-158, 2009

\section{South Greenland climatology and ablation \\ D. van As et al.}

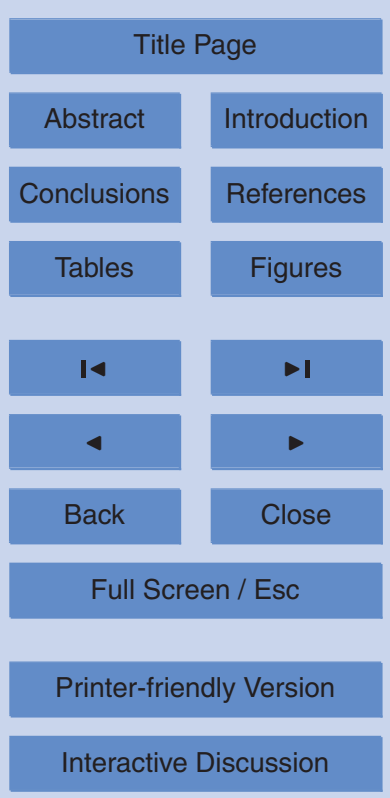


tures are recorded at Nuuk2, with monthly-mean values between -10 and $-20^{\circ} \mathrm{C}$. Here temperatures are comparable to St72, the upper and farther inland station in the southern transect, which was placed at a $350 \mathrm{~m}$ higher elevation (Table 1). The $T$ differences within the transects are largest in wintertime, when the vertical $T$ gradient more closely 5 reflects the free-atmospheric lapse rate. Interestingly, Tas1 measured higher $T$ than the lower-lying Tas3 station in summer. PROMICE observations of 2008 confirm the increase of near-surface temperature with elevation in summer. We speculate that the temperature at Tas3, and possibly in all low-lying regions of the south-eastern coastal zone, is constrained by to the cold East Greenland Ocean current. We do not see such 10 a summertime temperature inversion at other AWSs on ice around Greenland, partially because these stations are not placed close enough to the ocean, but chiefly because of the large cold content of the East Greenland current.

Land station data as measured by the DMI at Qaqortoq, Nuuk, and Tasiilaq, at respectively 58/73, 97/123, and 59/58 km from the lower/upper IceMon AWSs in the re15 gion are also shown in Fig. 2. Land and ice-sheet temperatures are correlated very well, with the exception of the summertime, when near-surface temperature over the ice is restricted by the melting surface.

The land stations recorded both the highest yearly-mean $\left(2.6,0.5\right.$, and $1.2^{\circ} \mathrm{C}$, resp.) and summer-mean $\left(8.9,7.4\right.$, and $7.9^{\circ} \mathrm{C}$, resp.) temperatures in 2003 since the be20 ginning of the data series in 1895 . Figure 2 confirms that 2003 temperatures were relatively high on the ice as well, but a clear identification of this record-year to date (Hanna et al., 2008) is impeded by the short record and data gaps therein. However, we can identify from the St71 and Nuuk2 data that temperatures remained relatively high in the autumn, up to October, and that even November and December were relatively 25 warm.

Also the data from the land stations show larger variability in $T$ in winter than in summer. Whereas conditions in wintertime are characterized by cold and stable air over the snow-covered surface, these situations may be disrupted by weather systems bringing heat to the near-surface atmosphere through a combination of factors such

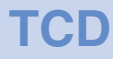

3, 117-158, 2009

\section{South Greenland climatology and ablation \\ D. van As et al.}

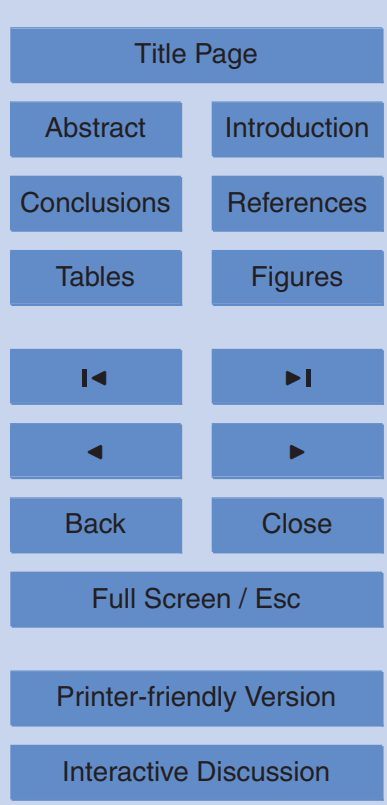


as horizontal advection of heat, increased longwave radiation from clouds, and enhanced vertical mixing due to strong winds. Such occasions can raise near-surface $T$ by tens of degrees, thus causing a large standard deviation in the measurements. In summer, differences are smaller as higher amounts of solar radiation and a lower bare 5 land surface albedo do not allow intensely cold and stable near-surface air. Also data from the GrIS interior show that winter temperatures are more variable (Shuman et al., 2001); even over a highly reflective surface solar radiation reduces the temperature deficit of the near-surface inversion layer, thereby reducing the potential impact of the inversion-layer removal during large-scale atmospheric disturbances.

10 In literature, 2007 has proven to be a record year in some respects, such as the year with the smallest sea ice extent in the northern hemisphere to date (Comiso et al., 2008), the largest surface melt extent in South Greenland (Tedesco et al., 2008), and the largest ablation on the western ice margin (Van de Wal et al., 2008). From temperatures both on the ice and on the land in South Greenland, 2007 cannot be considered an exceptional year since 2000 . The fact that temperatures are more variable during low-insolation periods causes yearly-mean temperature variability to be chiefly determined by conditions outside the summer season. For instance, even though the year 2007 experienced above-average summer temperatures for these three locations (8.4, 6.9 , and $7.0^{\circ} \mathrm{C}$, resp.), the yearly means were just below the 2001 to 2007 average (2.0, $20-0.3$, and $0.2^{\circ} \mathrm{C}$, resp.). Similarly, the below-average temperatures in $2002(1.4,-1.1$, and $0.2^{\circ} \mathrm{C}$, resp.) are caused by low temperatures early in the year. Evidently, yearlymean temperatures are not a good indicator of summer temperatures, and therefore certainly not of melt. Since the radiative properties of the surface are an important factor in atmospheric boundary layer development, a snow cover (on land or ice) will 25 impact near-surface temperatures significantly. This implies that a near-surface temperature change does not only respond to free-atmospheric forcings such as rising temperatures or more frequent passages of weather systems destroying the inversion layer, but also depends on the endurance of the wintertime snow cover, aiding inversion layer intensification. Rising and record yearly-mean temperatures at land stations

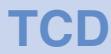

3, 117-158, 2009

\section{South Greenland climatology and ablation \\ D. van As et al.}

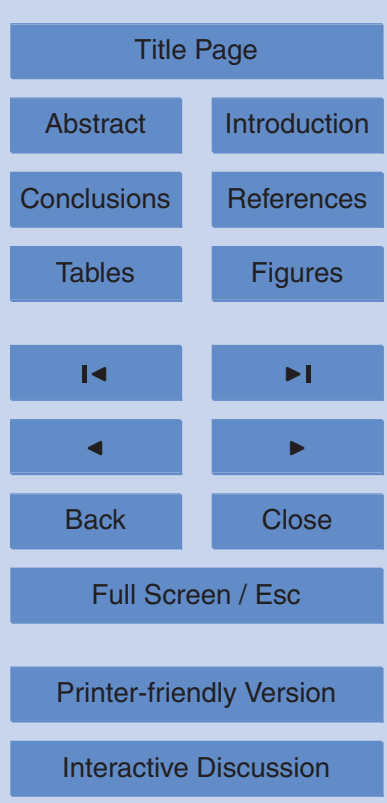


can thus have various origins.

For a view on spatial variability we have plotted the mean yearly cycles in $T, \mathrm{RH}$, and $W S$ in Fig. 3. No standard deviations are given due to the variable amount of values available from month to month (e.g. springtime WS measurements at Nuuk2 are few, 5 and missing at Tas1). Instead, all monthly-mean values are given and the mean yearly cycle is drawn. The highest year-round temperatures are found at St71 for reasons of latitude and elevation. The June and July values at Tas 1 are the exception, even though this AWSs was not yet up and running in the record-warm year of 2003. Temperaturewise, St71 has the longest summer, where above-freezing temperatures persist one to 10 two months longer than at the other sites. Nuuk2 is the coldest location, especially in winter. January is the coldest month at all three AWSs.

The $\mathrm{RH}$ plot in Fig. 3 shows less clear yearly cycles. In general $\mathrm{RH}$ is high with mean-monthly values between 70 and $90 \%$, caused by the high availability of moisture at the surface. $\mathrm{RH}$ at St71 is somewhat lower than at the other two locations in winter. During the melt season the readings at all locations are similar, less variable, and slightly increasing (possibly an artefact of the low amount of monthly means available).

Wind speed does have a distinct yearly cycle. As with $T$ and $\mathrm{RH}, W S$ is similar at the three locations in summer, with mean values between 2 and $4 \mathrm{~ms}^{-1}$. Tas 1 experiences slightly higher summer wind speeds. Winds at all locations are predominantly downslope (not shown): south for St71 and Tas1, and west for Nuuk2. This implies that these winds are likely to be katabatic in nature. Katabatic winds are dominantly present in the Greenland ablation zone (Duynkerke and Van den Broeke, 1994). In winter, mean WS at St71 and Nuuk2 increases by a factor two to three - in spite of accumulated snow effectively reducing sensor height - due to a better developed katabatic flow.

25 Wintertime WS at Tas1 is about twice as large as at the other two sites with mean values over $8 \mathrm{~ms}^{-1}$. Winds can be particularly strong in Southeast Greenland because of so-called piteraq events, which will be discussed further below.

Figure 4 zooms in on summer conditions in the ablation area. We show the daily cycles in 2-m temperature, relative humidity, and wind speed, along with surface tem-

\section{South Greenland climatology and ablation \\ D. van As et al.}

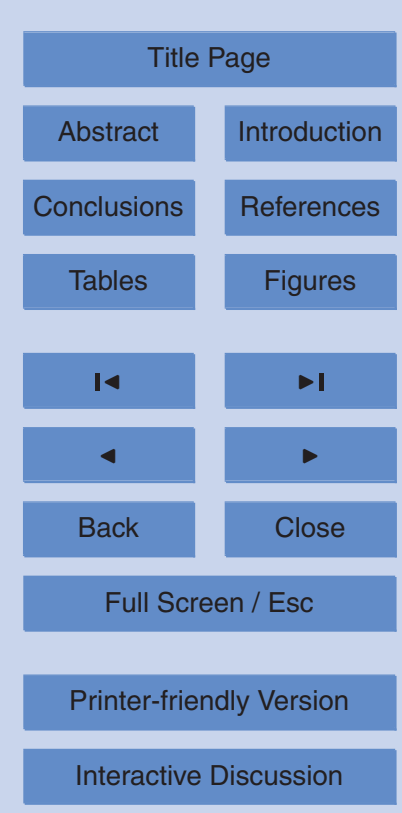


perature at the three sites, averaged over July and August when the presence of a bare ice surface at all three sites is most likely. The surface temperatures were calculated using the SEB model described in the Methods section. The 2-m values were inferred from their measurement heights using the known stability-dependent curvature with 5 height of these parameters. Mean near-surface temperature is highest at St71 $\left(3.9^{\circ} \mathrm{C}\right)$ and lowest at Nuuk2 $\left(2.9^{\circ} \mathrm{C}\right)$, which seems logical given their differences in latitude and elevation (Table 1). Remarkably, both highest and lowest temperatures are measured at Tas1, where a larger - but still small - daily cycle of about $2^{\circ} \mathrm{C}$ is recorded.

The mean surface temperatures are at the melting point between about 7 and $19 \mathrm{~h}$ 10 local time. At Tas 1 this period is shifted to earlier hours, as it has the most easterly position and differs 43 min from Nuuk2 in solar time. The mean daily cycles show small amplitudes. At Nuuk2 the lowest mean surface temperatures are calculated $\left(-1.4^{\circ} \mathrm{C}\right)$, due to stronger radiative cooling as we will see below. During clear nights surface temperatures drop to $-4.8^{\circ} \mathrm{C}$ here. At all stations surface melt persists during cloudy nights caused by higher $L R_{\text {in }}$ values. At Tas 1 even mean surface temperature is always close to melting ( $\min .-0.5^{\circ} \mathrm{C}$ ), due to higher cloud amounts, and stronger winds that transport more heat towards the surface by vertical mixing.

Relative humidity is similar at the three sites, showing values around $80 \%$. At Nuuk2 the values are a few percent lower than at the other sites. The small daily cycle is due to the small cycle in temperature, on which relative humidity is strongly dependent. The highest relative humidity is recorded when the temperature is lowest at night, and the air can hold less moisture.

Wind speed is largest at Tas1 (3-4 ms ${ }^{-1}$ ), and lowest at St71 (about $2 \mathrm{~ms}^{-1}$ ), where katabatic flow is divergent. The daily cycles are small, with amplitudes of about $0.5 \mathrm{~ms}^{-1}$ for Nuuk2 and Tas1, and no significant cycle at St71. The largest wind speeds are experienced at night.

\section{South Greenland climatology and ablation \\ D. van As et al.}

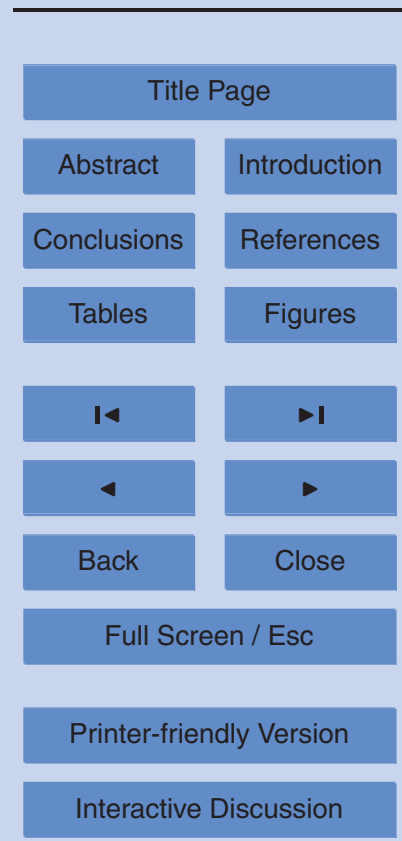


Taking a closer look at the near-surface winds at Tas1 (Fig. 5) we observe that most often winds originate from the approximate north, between 300 and 60 degrees, which agrees with the local north-to-south slope direction. What is not seen in the other two 5 regions is that the strongest winds originate from a very specific (and more westerly) direction of about $320^{\circ}$. For increasing wind speeds the directions becomes even more westerly. Furthermore, the wind maxima at Tas1, with a largest recorded value of $32.9 \mathrm{~ms}^{-1}$ at about $3 \mathrm{~m}$, are roughly $40 \%$ larger than at St71 and Nuuk2 (22.0 and $24.7 \mathrm{~ms}^{-1}$, respectively). These high wind speeds occur several times per year, chiefly 10 in wintertime, explaining the enhanced yearly cycle for Tas 1 in Fig. 3.

These storms are known as piteraqs, which are exceptional and destructive strongwind events originating from the inland ice. Indicative of their strength is that data early in the year are often missing due to repeated wind damage to Tas1's wind-speed sensor (Fig. 3). A historic piteraq event on 6 February 1970 (Rasmussen, 1989) even caused severe damage to the town of Tasiilaq in spite of being situated a few tens of kilometres from the inland ice.

Figure 6 shows near-surface $T$ and WS data for Tas 1 in December 2004. This month experienced at least five strong-wind events (the last one destroying the wind sensor), and is the windiest month in our records. Generally, the strongest winds over an ice sheet are produced by synoptic-scale weather systems and tend to be relatively warm (Van As et al., 2007) due to the removal of the cold near-surface inversion layer, the presence of clouds increasing net radiation over snow surfaces (Ambach, 1974), and horizontal advection of heat. Striking is the anti-correlation between $T$ and $W S$ in Fig. 6. Where $T$ drops by $10^{\circ} \mathrm{C}$ or more, WS rises by $25 \mathrm{~ms}^{-1}$ within hours. Irrespective of the cause of the sudden drop in $T$, the high potential energy of the relatively cold and dense layer of air over the ice sheet is released by a large acceleration in down-slope direction. The directional preference of the measured strong winds (Fig. 5) indeed implies a strong link to the orography of the Greenland Ice Sheet, i.e. that piteraqs are

\section{South Greenland climatology and ablation \\ D. van As et al.}

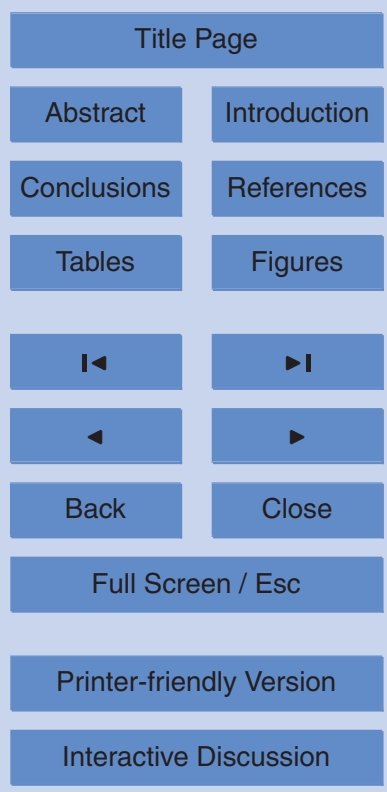


intense katabatic winds.

The katabatic nature of piteraqs was already established by Kaas and Isaksen (1989), who presented two scenarios for their development. Firstly, katabatic flow over the ice sheet can be enhanced by synoptic-scale flow when a low-pressure

5 system is present off the southeast coast of Greenland, aligning the katabatic and free-atmospheric forcings. Secondly, they claim that katabatic winds will be intense when there are cold and dense air masses present on top of the ice sheet. The anticorrelation between temperature and wind speed in Fig. 6 certainly supports the second scenario. An inspection of MODIS imagery confirms this to be a dominant mech10 anism: Figure 7 shows the cloud structures during three significant piteraq events, revealing that air originates from the western or northern regions of the ice sheet, where it is presumably pushed onto the high ice by the large-scale circulation. During the transport over the ice the air cools by interaction with the surface and orographic lifting, and moisture condensates to form cloud bands. As the airflow is forced in a more 15 southerly direction by the central dome of the ice sheet, it reaches the relatively steep down-sloping surface of Southeast Greenland. Here it accelerates down in clear-sky conditions, with largest wind speeds occurring when the temperature contrast between the near-surface air and free atmosphere is largest. Clear skies prevail tens or hundreds of kilometres over the ocean after reaching the coast. On occasion the piteraqs are visualised over the ocean by blowing snow (such as on 5 November 2006, see Fig. 7). The band of blowing snow/strong winds strikes at the same $\sim 200 \mathrm{~km}$ of coastline every time, ranging from about $63^{\circ} 50^{\prime} \mathrm{N}$ to $65^{\circ} 40^{\prime} \mathrm{N}$, where we had our AWSs.

Klein and Heinemann (2002) state that katabatic flow can also be intensified when warm air is advected over the ice by a synoptic low over the Atlantic ocean, increasing the katabatic pressure gradient resulting from the temperature contrast between the cold near-surface atmospheric layer and the warm free atmosphere. Also, they argue that piteraq events can contribute to or trigger the development of mesocyclones, which are occasionally observed at the Southeast Greenland coast.

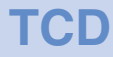

3, 117-158, 2009

\section{South Greenland climatology and ablation \\ D. van As et al.}

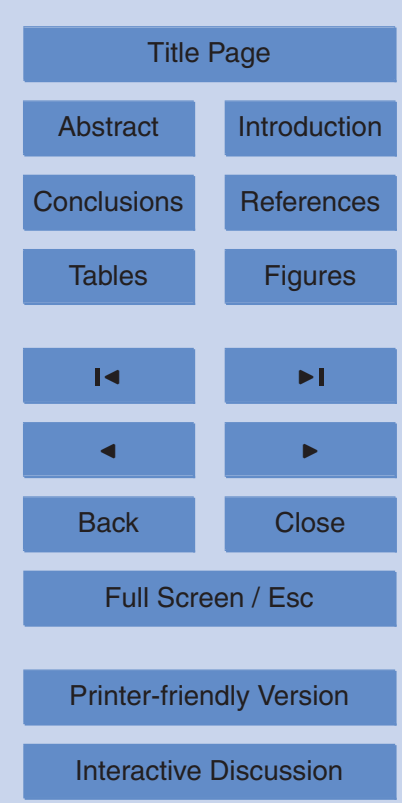




\subsection{Summer surface energy budget}

In calculating the surface energy fluxes from the IceMon dataset we can only make use of four ablation seasons during which we have the full set of necessary observations. Available SEB years are 2001 and 2003 at St71, 2003 at Nuuk2, and 2004 at Tas1. The 5 data coverage is insufficient for a year-to-year mass-balance variability study, but does allow us to investigate the different contributions to summer melt, and how these vary between the three locations. We define "summer" as July and August here (during which a bare ice surface is likely to be found at the three sites) to use comparable periods. Full snow ablation season calculations are hampered by incomplete data sets. We focus on net ablation by taking only periods with a bare ice surface into account.

Summer-mean incoming shortwave radiation is highest at Nuuk2 (max. $\sim 600 \mathrm{Wm}^{-2}$, not shown), as it is located farther inland than the other stations, shielded from clouds by mountainous terrain. Tas1 and St71, positioned in South(east) Greenland where clouds and precipitation occur frequently, have no significant barriers against low15 pressure systems over the Atlantic, and receive a lower amount of solar radiation $\left(\sim 500 \mathrm{Wm}^{-2}\right)$. Broadband surface albedo at St71 is 0.22 for the ice melt season $(26 \%$ in 2001 and $19 \%$ in 2003), indicative of wet glacier ice with a high dirt content. At Nuuk2 and Tas1 we find bright glacier ice, with mean albedo values of 0.46 and 0.44 , respectively. These values are lower than those of bare ice at the Kangerlussuaq transect ( 0.55, Van den Broeke et al., 2008a), but within the range of values measured in Northeast Greenland (0.42-0.56, Konzelmann and Braithwaite, 1995). As a result of differences in $S R_{\text {in }}$ and albedo, summer-mean net shortwave radiation is largest at St71 (max. $\sim 385 \mathrm{Wm}^{-2}$ ), and smallest at Tas1 (max. $\sim 305 \mathrm{Wm}^{-2}$ ) (Fig. 8). The phase shift in the net shortwave radiative signals is partly due to the longitudinal differences between the stations, and partly due to characteristic of the ice (such as hummocks) the shortwave radiation sensors were mounted over.

Summer-mean $L R_{\text {net }}$ is negative at all three sites, and most negative at Nuuk2 (mean of $-35.2 \mathrm{Wm}^{-2}$, see Table 3). St71 and Tas1 on average lose less than half as much

\section{South Greenland climatology and ablation \\ D. van As et al.}

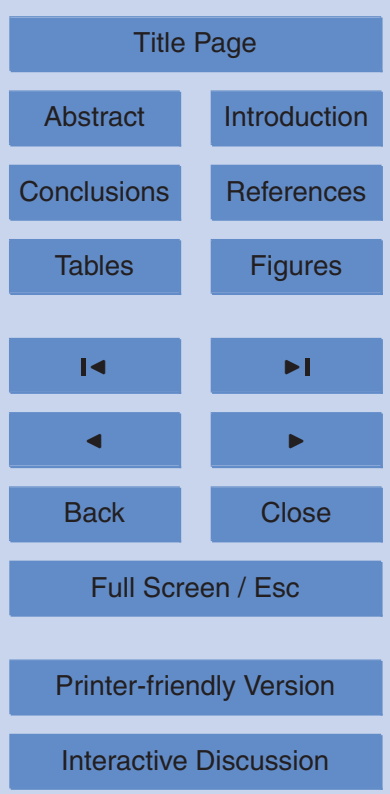

Interactive Discussion 
through LR. St71 and Nuuk2 show similar variability with a maximum around noon. This peak is not necessarily realistic as outgoing longwave radiation is constant over a melting surface, and we expect incoming longwave radiation to be correlated to air temperature (Fig. 4). Since the observation of longwave radiation requires the body 5 temperature of the sensors it is likely that the measurement of body temperature was overestimated in the instruments. An argument in favour of this is that the midday peak is not seen at Tas1, where the station did not record sensor casing temperature, which is why we used air temperature for $L R_{\text {in }}$ calculation instead.

The sensible heat fluxes at St71, Nuuk2, and Tas1 have summer-mean values of $1034.4,37.5$, and $48.9 \mathrm{Wm}^{-2}$, respectively (Table 3 ), and are fairly constant throughout the mean day (Fig. 8). Values at St71 are lowest due to low wind speeds, in spite of having the highest mean temperature. $\mathrm{SH}$ at Nuuk2/Tas1 peaks during the night/morning following the cycle in wind speed (Fig. 4).

The mean latent heat fluxes at the three sites are small; absolute summer values 15 are at most $4 \mathrm{Wm}^{-2}$ (Table 3), and hourly values between -13 and $+8 \mathrm{Wm}^{-2}$ (Fig. 8). The daily cycles are surprisingly different between locations: $L H$ at Tas 1 is negative at night and positive during the day, at Nuuk2 it shows an opposite cycle, albeit with mostly negative values, and at St71 it is constant at about $4 \mathrm{Wm}^{-2}$ all day. The differences between these records originate from the near-surface gradients in specific humidity (not shown). Figure 4 shows that near-surface $\mathrm{RH}$ is reasonably constant. We therefore argue that the changes in $T$ gradients are a fair indicator for changes in $\mathrm{LH}$. Figure 4 shows that where Nuuk2 has the largest $0-2 \mathrm{~m}$ temperature gradients at night due to a more distinct cycle in surface $T$ than in air $T$, the opposite is true at Tas 1 where air temperature shows the largest daily variability and gradients are largest during the day, thus explaining the opposite cycles.

At Tas 1 the sub-surface heat flux has the smallest daily cycle in response to the small cycle in surface temperatures. Absolute fluxes during the day are smaller than at St71 and Nuuk2, since at these locations more cold content is built up due to lower surface temperatures at night. On average the sub-surface heat flux is small for melting

\section{South Greenland climatology and ablation \\ D. van As et al.}

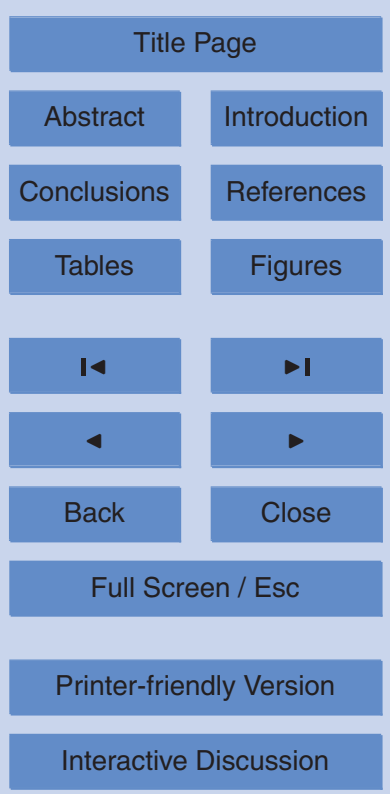


ice surfaces; $0.5 \mathrm{Wm}^{-2}$ at St71, 0.7 Wm $\mathrm{Wm}^{-2}$ at Nuuk2, and $0.4 \mathrm{Wm}^{-2}$ at Tas1.

Adding the surface energy components leaves the energy available for melt, Eq.(3). Figure 8 shows that midday melt energy at St71 is 20-25\% larger than at the other stations. The daily cycle is very similar to that of net shortwave radiation, both in amplitude 5 as in phase, illustrating the dominance of the latter on the surface energy balance over bare ice. A difference is that due to the contribution of $L R$ and $S H$, melt energy at Tas 1 is larger than at Nuuk2, though at the latter site more shortwave radiation is absorbed. On average melt energy values are also positive at night resulting from considerable nocturnal melt during overcast conditions. The mean $M$ values in Table 3 translate into surface melt rates of $4.9 \mathrm{~cm}$ (St71), $3.8 \mathrm{~cm}$ (Nuuk2), and $4.4 \mathrm{~cm}$ (Tas1) of ice per day.

Table 3 confirms that $S R_{\text {net }}$ provides most of the energy available for ice melt, especially at Nuuk2 (101\%) where $L R_{\text {net }}$ and $S H$ cancel each other out. $S H$ is a large energy supplier at all sites with average contributions to melt ranging from 20-32\%. Even though instantaneous values of $\mathrm{LH}$ and $\mathrm{SSH}$ can contribute significantly to the surface energy budget, their mean values constitute a small portion of $M$.

\subsection{Surface mass budget}

We address the net surface mass budget at the three sites by calculating the surface energy balance over the full bare-ice season. We used measured albedo values to determine the surfacing of the ice horizon in summer, and the onset of the accumulation season in autumn (Fig. 9). We assume the surface to be snow-free for the periods with relatively low albedo values. Figure 9 shows that for the two years at St71 and one year at Nuuk2 and Tas1, the ice horizon was reached in June (day 152/153-181/182). For Nuuk2 we have to assume for the moment that the net-ablation season started at the beginning of the data series. The first significant snowfall event ending the ice ablation season occurs in September or October. However, it is not necessarily true that these snow layers survive the winter, judging from the drop in albedo at St71 in 2001, or at Nuuk2 in 2003.

\section{South Greenland climatology and ablation \\ D. van As et al.}

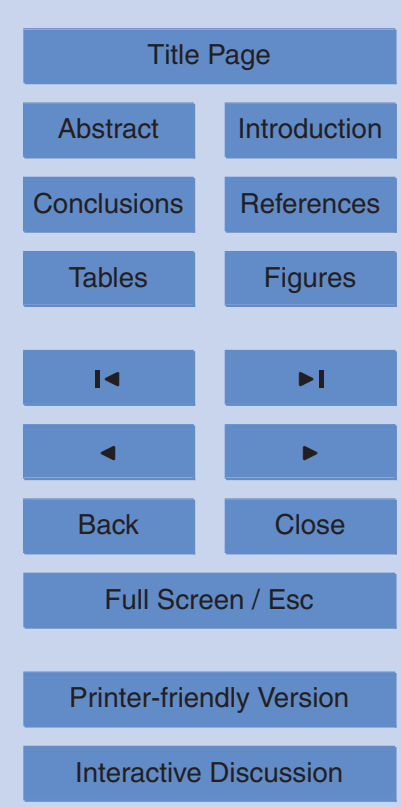

Interactive Discussion 
Mass loss/gain by sublimation/deposition is added to ice melt to obtain ablation values. We will not discuss these processes separately; in our calculations ice melt is typically 50-100 times larger than mass loss or gain by sublimation and deposition.

The lower panel of Fig. 9 shows the calculated ice ablation at the three stations for 5 the ablation years that they were fully operational. In mid-summer (day 182-227: July and first half of August), ice-ablation rates are fairly constant; variations in ablation rate are chiefly due to cloud amounts. The largest ablation rate is calculated at St71 in 2003 , where $\sim 6 \mathrm{~cm}$ of ice were ablated during the average July day. Contributing to this were the very low surface albedo and high summer temperatures (Table 3 ). The lowest 10 ablation rates are found at Nuuk2 for the same year ( $\sim \mathrm{cm}$ per day). In comparison, mid-summer ablation rates of 3-6 cm per day were found in Northeast Greenland by Braithwaite et al. (1998). Where the mean daytime melt energy in Northeast Greenland is smaller than in South Greenland (max. $\sim 270 \mathrm{Wm}^{-2}$ ), the nighttime melt energy is larger and compensates ( $\mathrm{min} . \sim 50 \mathrm{Wm}^{-2}$ ).

15 Even though at St71 the snow was ablated about two weeks earlier in 2001 than in 2003, the total ablation was larger in 2003 (4.55 m versus $4.21 \mathrm{~m}$ in 2001, see Table 4) due to the larger ablation rate, but also because of the warm 2003 autumn (Fig. 2), allowing ablation to continue longer. Tas1 experienced more ablation in 2004 (3.59 m) than Nuuk2 in $2003(3.36 \mathrm{~m})$; the higher ablation rate at Tas1 compensated for the shorter ablation season. In comparing these two results we must take into account the high 2003 temperatures in support of high melt values. On the other hand, ablation was possibly larger at Nuuk2 as we missed the start of the ice-ablation season.

This can also be concluded from Braithwaite and Olesen (1993), who reported a mean ablation value of more than five metres of ice per year for 1979 to 1986 . Their 25 measurements were taken on a glacier $25 \mathrm{~km}$ south of Nuuk2, at $790 \mathrm{~m}$ above sea level. The large difference with Nuuk2 can partly be attributed to differences in surface albedo (Braithwaite et al., 1998), and to some extent to the differences in surroundings (mountainous terrain versus an exposed ice field). However, Braithwaite and Olesen (1989) mention "little or no winter snow cover" below about $900 \mathrm{~m}$ surface elevation,

\section{South Greenland climatology and ablation \\ D. van As et al.}

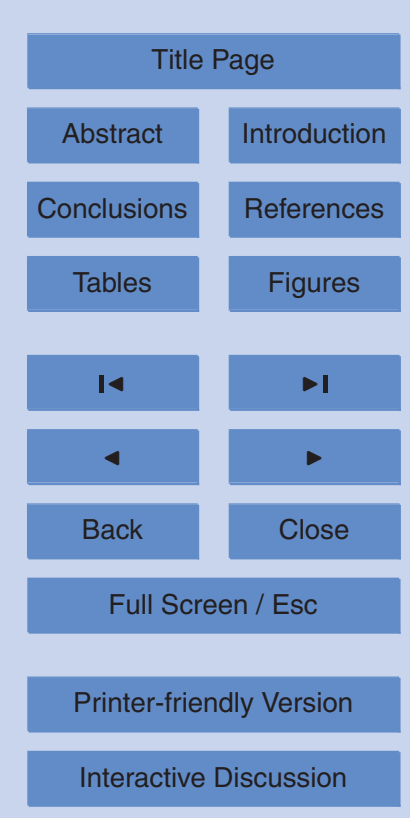


implying that we indeed may not have captured all of the ice ablation at Nuuk2. More recent PROMICE AWS data on the location of the stake transect confirms lacking wintertime accumulation for early 2008, causing ice ablation to start late April. In 2008, $25 \%$ of all ablation occurred prior to the date Nuuk2 was installed in 2003 (11 June).

5 Adjusting our calculated value for this, we arrive at $4.48 \mathrm{~m}$ of net ice ablation, which must be considered an upper estimate, as a snow layer in spring 2003 may have been present and delaying the surfacing of bare ice.

Net ablation values are also presented by Van de Wal et al. (2005) for a stake transect on the ice margin near Kangerlussuaq, $260 \mathrm{~km}$ north of Nuuk2. A linear inter10 /extrapolation of their 1990 to 2003 mean values gives $5.05 \mathrm{~m}$ of ice ablation at $300 \mathrm{~m}$ (St71), $3.57 \mathrm{~m}$ at $590 \mathrm{~m}$ (Tas1), and $2.35 \mathrm{~m}$ at $900 \mathrm{~m}$ above sea level (Nuuk2). The first value is higher than our calculations at St71, as the lower ice margin near Kangerlussuaq also receives little wintertime precipitation (Van den Broeke et al., 2008b). The second value agrees very well with our 2004 estimate at Tas1. The last value is lower 15 than for 2003 at Nuuk2, since the 900-m elevation line at Kangerlussuaq is located much farther onto the ice sheet than in the Nuuk region due to a gentler surface slope. Comparison is biased since in the early nineties a few years with a less negative mass balance in the ablation zone occurred. Van de Wal et al. (2008) show that 2003 was indeed a year with high ablation, only surpassed by 2007 to date.

20 We know from visits to the IceMon stations and pressure transducer measurements that net ablation can be larger than the values shown in Fig. 9. For instance, from pressure transducer data we estimate six meters ice ablation at St71 in 2005, starting around 4 June (day 155), and ending late October ( day 300). In 2006 roughly $5.5 \mathrm{~m}$ of ice ablation was measured between day 170 and 300 (mid June-late October). Even 25 though we do not have ablation calculations at St71 in 2005 and 2006, these measurements suggest that we potentially underestimate ablation at St71. On the other hand, the melt seasons were longer in 2005 and 2006 than in 2001 and 2003, which, as we will see below, can easily explain the differences.

Since the calculated ablation values could be imprecise due to reasons of sensor

\section{South Greenland climatology and ablation \\ D. van As et al.}

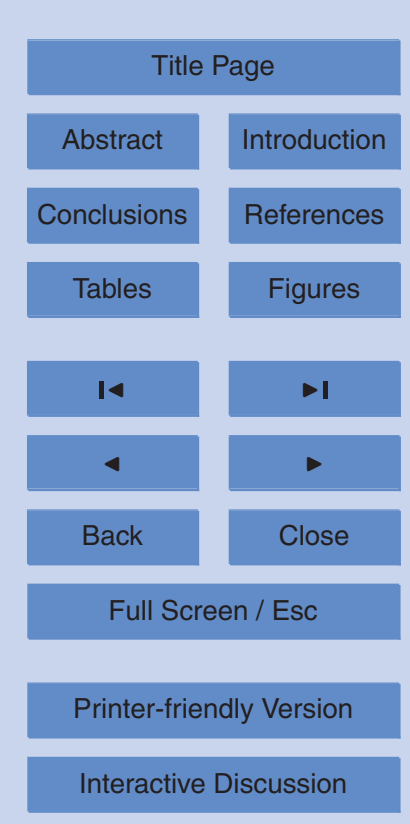


inaccuracy or wrong assumptions in energy flux calculations, we investigate the impact of such factors on the total ablation. Table 4 shows how a large change in one of the measured or modelled parameters would change the total ablation as shown in Fig. 9. We see that a $10 \%$ measurement inaccuracy in net shortwave radiation results in a 5 change in ice ablation of 0.28 to $0.39 \mathrm{~m}$, with the lowest change found at Tas1, where $S R$ dominance is smallest (Table 3 ). The sensitivity to a similar change in $L R_{\text {net }}$ would be small due to the fact that $L R_{\text {net }}$ is small as the incoming and outgoing fluxes largely cancel each other out. A measurement inaccuracy in $L R_{\text {in }}$, however, would impact the mass budget severely: a $5 \%$ increase adds $\sim 0.45 \mathrm{~m}$ of ablation at St71, and $\sim 0.34 \mathrm{~m}$ at 10 Nuuk2 and Tas1. A continuous $0.5^{\circ} \mathrm{C}$ temperature overestimation or a $5 \%$ inaccuracy in relative humidity yields a smaller, but still substantial impact on the mass budget of 0.12 to $0.17 \mathrm{~m}$. A $0.5 \mathrm{~ms}^{-1}$ increase in wind speed affects ablation significantly at St71 $(\sim 0.3 \mathrm{~m})$, but is comparable to temperature and humidity changes at Nuuk2 and Tas1. Sensitivity to air pressure - more recent measurements show that variability is 15 generally within $20 \mathrm{hPa}$ of the values chosen in this study - is very small, justifying our choice to keep it at a fixed value. The same can be concluded to some extent for our choice of the initial sub-surface temperature profile: lowering initial temperatures from $0^{\circ} \mathrm{C}$ to $-5^{\circ} \mathrm{C}$ decreases ablation by 2 to $3 \%$. Of high importance is the choice of surface roughness for momentum, and therewith those of heat and moisture (Smeets 20 and Van den Broeke, 2008). A not unrealistic multiplication of $z_{0 m}$ by 5 results in an ice ablation increase of 0.22 to $0.46 \mathrm{~m}$. But most striking is the impact of the timing of the ice ablation season. Depending on the location, a ten-day shift adds/removes 0.34 to $0.70 \mathrm{~m}$ of ice to/from the mass budget. The year-to-year impact differs judging from the St71 results, but the absolute size is considerable nonetheless. Missing wintertime 25 accumulation, such as in the lower regions of the ice margin in the Nuuk area, will therefore allow for relatively large net ablation values. Our adjusted value of $4.48 \mathrm{~m}$ at Nuuk2 proves that even though the melt rate is the smallest of our three locations, the total ice ablation can be (almost) largest due to (lack of) wintertime accumulation.

The discrepancy between the lower calculated and higher measured ice ablation

\section{South Greenland climatology and ablation \\ D. van As et al.}

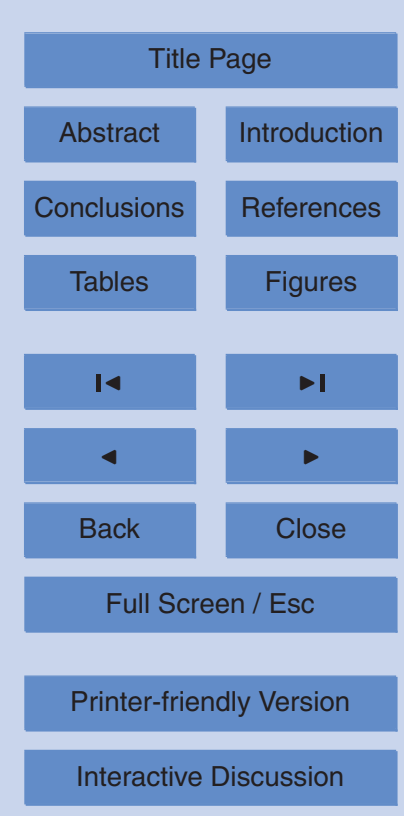


amount discussed above can thus be explained by differences in ice ablation season length. The importance of the timing of the ice surfacing merits a short assessment of wintertime accumulation variability. For this we use all available surface height change observations at the two southernmost GC-Net stations, named after their locations:

5 Saddle and South Dome (Fig. 1). Figure 10 shows the surface height increase of each November to April period since the erection of the stations in 1997, scaled by the mean value. The scatter is large, but we can identify that the winters of 2000/2001 and 2003/2004 had below-average accumulation, whereas 2002/2003 was a winter with high precipitation in the region. It is highly uncertain how these values translate 10 into wintertime accumulation at lower elevation, and even more so how we can draw conclusions about the start of the ice ablation season from this, but at least both Fig. 9 and 10 suggest a thicker wintertime snow cover in 2003 than in 2001 . The fact that wintertime accumulation is significant at St71 has been experienced during station visits, such as an observed $2.5 \mathrm{~m}$ snow cover at St71 in April 2006. The southeast coast is known for high precipitation, but it is likely that most accumulation here is eroded during piteraq events, transporting the snow to the ocean. The contrast is large with the low-precipitation areas in the southwest of Greenland. Since the surface mass budget in the lower southwest GrIS margin is not complicated by large variability in wintertime accumulation, the mass balance is expected to be less variable on interannual time scales.

\section{Summary}

This paper discusses atmospheric variability, and the surface energy and mass budgets in three low-elevation regions of the Southern Greenland ice sheet. The bulk of the data was collected by means of automatic weather stations placed in the ablation zone of the ice sheet. We made use of a surface energy balance model to calculate net ablation, and compared to observations where possible.

The southern tip of the ice sheet, near the village of Qassimiut, receives the largest

\section{South Greenland climatology and ablation \\ D. van As et al.}

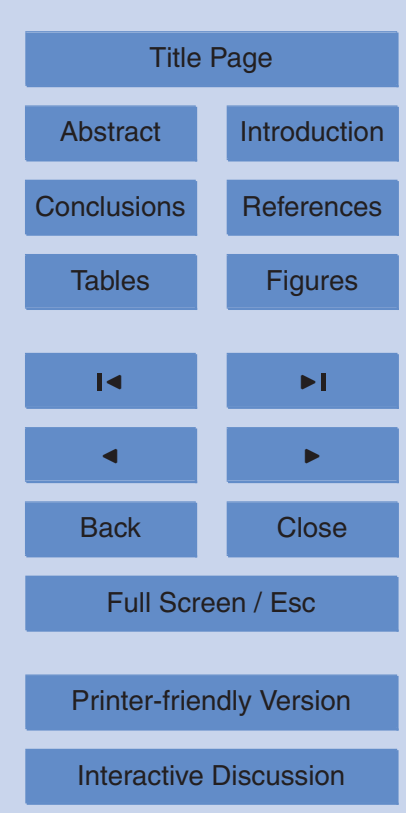


amounts of solar radiation in clear-sky conditions and is reasonably exposed to advection of heat from over the ocean. This, combined to a low surface albedo ( 0.2) at low elevation, causes relatively high summer temperatures and ablation up to six metres per year. A few metres of accumulation occur in wintertime.

$5 \quad$ The south-western ice sheet margin in the Nuuk region is more shielded from largescale atmospheric disturbances over the ocean by $100+\mathrm{km}$ of mountainous terrain, causing relatively high mean solar radiation amounts and low precipitation. Especially the lack of precipitation at low elevation on the ice favours considerable net ablation; without a snow layer to melt away in spring, ice ablation starts as early as late April. In 10 spite of a higher ice albedo (0.46), ablation can be higher here than in the south.

The south-eastern ice margin near Tasiilaq resembles our southern location, as it is exposed to the oceanic air masses, and receives significant amounts of precipitation. Since mean albedo is not particularly low (0.44) and summer temperatures not extraordinarily high, net ablation is smaller than at the southern location. But the region 15 sets itself apart in other ways. For instance, near-surface temperatures increase with elevation in summer, causing the upper weather station to record higher temperatures than the lower, in contrast to most other Greenlandic observations. This is believed to be related to the cold East Greenland Ocean current, reducing air temperature at low elevation and close to the coast. Also, the region is known for the occurrence of strong-wind events named piteraqs. These are strong katabatic winds originating from the Greenland inland that can have a significant impact on the surface mass budget in the region through blowing snow.

The three regions in South Greenland discussed in this paper have in common that variability in atmospheric parameters is largest in winter, from which we conclude that 25 year-to-year variability is chiefly established by changes in wintertime values. Also, shortwave radiation (and thus albedo) is the dominant factor when it comes to surface melt. However, we found that wintertime accumulation is of crucial importance for the amount of net ablation each year. Year-to-year changes in the surface mass budget in the Greenland ablation zone will reflect these changes in wintertime accumulation.

\section{South Greenland climatology and ablation \\ D. van As et al.}

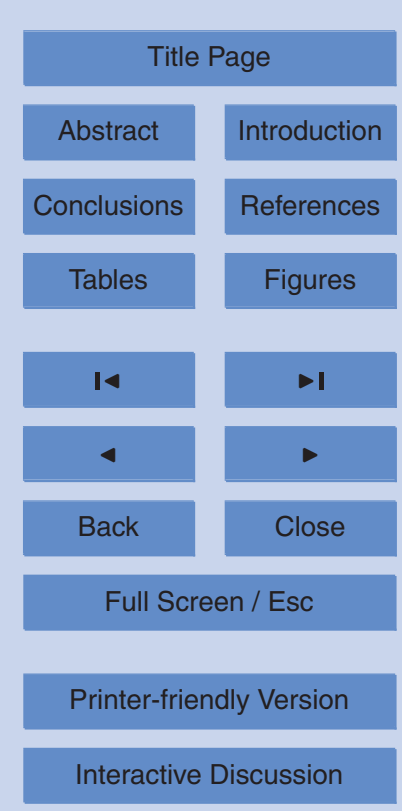

Interactive Discussion 
Acknowledgements. The IceMon automatic weather stations were funded by the Danish Ministry of Environment (currently Climate and Energy) through the DANCEA programme of the Danish Environmental Protection Agency. The research for this paper has been performed within the Programme for Monitoring of the Greenland Ice Sheet (PROMICE), also funded 5 through DANCEA. We thank the DMI for the usage of their valuable land-station data in Greenland, as we do the Steffen group at CIRES for providing accumulation data from the GC-Net.

\section{References}

Ambach, W.: The influence of cloudiness on the net radiation balance of a snow surface with high albedo, J. Glaciol., 13, 73-84, 1974.

Anderson, P. S.: A method for rescaling humidity sensors at temperatures well below freezing, J. Atmos. Ocean. Tech., 11, 1388-1391, 1994.

Bamber, J. L., Layberry, R. L., and Gogenini, S. P.: A new ice thickness and bed data set for the Greenland ice sheet 1: Measurement, data reduction, and errors, J. Geophys. Res., 106, 33773-33780, 2001.

15 Bøggild, C. E., Olesen, O. B., Ahlstrøm, A. P., and Jørgensen, P.: Automatic glacier ablation measurements using pressure transducers, J. Glaciol., 50, 303-304, 2004.

Bougamont, M., Bamber, J. L., Ridley, J. K., Gladstone, R. M., Greuell, W., Hanna, E., Payne, A. J., and Rutt, I.: Impact of model physics on estimating the surface mass balance of the Greenland ice sheet, Geophys. Res. Lett., 34, L17501, 2007.

Box, J. E.: Survey of Greenland instrumental temperature records: 1873-2001, Int. J. Climatol., 22, 1829-1847, 2002.

Box, J. E., Bromwich, D. H., Veenhuis, B. A., Bai, L. S., Stroeve, J. C., Rogers, J. C., Steffen, K., Haran, T., and Wang, S. H.: Greenland ice sheet surface mass balance variability (19882004) from calibrated polar MM5 output, J. Climate, 19, 2783-2800, 2006.

25 Box, J. E. and Rinke, A.: Evaluation of Greenland Ice Sheet surface climate in the HIRHAM Regional Climate Model using automatic weather station data, J. Climate, 16, 1302-1319, 2003.

Box, J. E. and Steffen, K.: Sublimation on the Greenland ice sheet from automated weather station observations, J. Geophys. Res., 106, 33965-33981, 2001.

\section{South Greenland climatology and ablation \\ D. van As et al.}

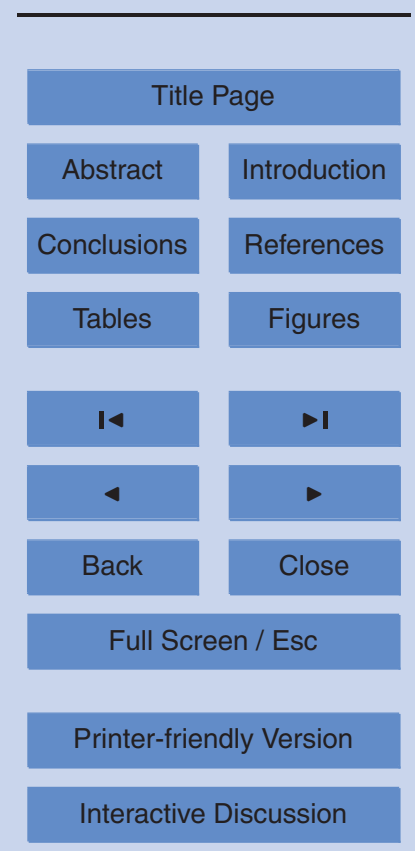


Braithwaite, R. J., Konzelmann, T., Marty, C., and Olesen, O. B.: Reconnaissance study of glacier energy balance in North Greenland, 1993-94, J. Glaciol., 44, 239-247, 1998.

Braithwaite, R. J. and Olesen, O. B.: Detection of climate signals by inter-stake correlations of annual ablation data, Qamanârssûp Sermia, west Greenland, J. Glaciol., 35, 253-259, 51989.

Braithwaite, R. J. and Olesen, O. B.: Seasonal variation of ice ablation at the margin of the Greenland ice sheet and its sensitivity to climate change, Qamanârssûp Sermia, west Greenland, J. Glaciol., 39, 267-274, 1993.

Brock, B. W., Willis, I. C., and Shaw, M. J.: Measurement and parameterization of aerodynamic roughness length variations at Haut Glacier d'Arolla, Switzerland, J. Glaciol., 52, 281-297, 2006.

Comiso, J. C, Parkinson, C. L., Gersten, R., and Stock, L.: Accelerated decline in the Arctic sea ice cover, Geophys. Res. Lett., 35, L01703, doi:10.1029/2007GL031972, 2008.

Cook, A. J., Fox, A. J., Vaughan, D. G., and Ferrigno, J. G.: Retreating glacier fronts on the 15 Antarctic Peninsula over the past half-century, Science, 308, 541-544, 2005.

Duynkerke, P. G. and Van den Broeke, M. R.: Surface energy balance and katabatic flow over glacier and tundra during GIMEX-91, Global Planet. Change, 9, 17-28, 1994.

Fettweis, X., Gallee, H., Lefebre, F., and Van Ypersele, J. P.: The 1988-2003 Greenland ice sheet melt extent using passive microwave satellite data and a regional climate model, Clim.

20 Dynam., 27, 531-541, 2006.

Hanna, E., Huybrechts, P., Steffen, K., Cappelen, J., Huff, R., Shuman, C., Irvine-Fynn, T., Wise, S., and Griffiths, M.: Increased runoff from melt from the Greenland Ice Sheet: A response to global warming, J. Climate, 21, 331-341, 2008.

Harrison, R. G., Chalmers, N., and Hogan, R. J.: Retrospective cloud determinations from surface solar radiation measurements, Atmos. Res., 90, 54-62, 2008.

Holtslag, A. A. M. and De Bruin, H. A. R.: Applied modelling of the night-time surface energy balance over land, J. Appl. Meteorol., 27, 689-704, 1988.

Joughin, I., Howat, I., Alley, R. B., Ekstrom, G., Fahnestock, M., Moon, T., Nettles, M., Truffer, M., and Tsai, V. C.: Ice-front variation and tidewater behavior on Helheim and Kangerdso lugssuaq Glaciers, Greenland, J. Geophys. Res., 113, F01004, doi:10.1029/2007JF000837 2008.

Kaas, E. and Isaksen, L.: To Piteraq'er forudsagt af DK-LAM, Vejret, Dan. Meteorol. Soc., 2, 24-33, 1989.

\section{South Greenland climatology and ablation \\ D. van As et al.}

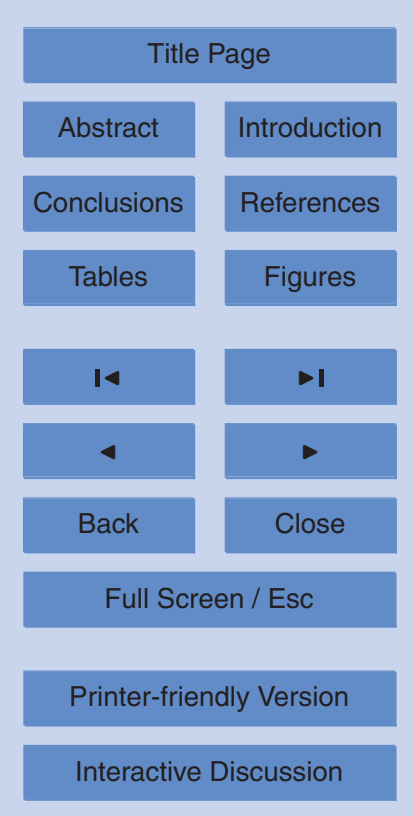


Klein, T. and Heinemann, G.: Interaction of katabatic winds and mesocyclones near the eastern coast of Greenland, Meteorol. Appl., 9, 407-422, 2002.

Konzelmann, T. and Braithwaite, R. J.: Variations of ablation, albedo and energy-balance at the margin of the Greenland ice-sheet, Kronprins-Christian Land, eastern north Greenland, J.

5 Glaciol., 41, 174-182, 1995.

Krabill, W., Frederick, E., Manizade, S., Martin, C., Sonntag, J., Swift, R., Thomas, R., Wright, W., Yungel, J.: Rapid thinning of parts of the southern Greenland ice sheet, Science, 283, 1522-1524, 1999.

Mote, T. L.: Greenland surface melt trends 1973-2007: Evidence of a large increase in 2007, Geophys. Res. Lett., 34, L22507, doi:10.1029/2007GL0319762007.

Parizek, B. R. and Alley, R. B.: Implications of increased Greenland surface melt under globalwarming scenarios: ice-sheet simulations, Quaternary Sci. Rev., 23, 1013-1027, 2004.

Paulson, C. A.: The mathematical representation of wind speed and temperature profiles in the unstable atmospheric surface layer, J. Appl. Meteorol., 9, 857-861, 1970.

15 Podlech, S., Mayer, C., and Bøggild, C. E.: Glacier retreat, mass-balance and thinning: the Sermilik Glacier, South Greenland, Geogr. Ann. A, 86, 305-317, 2004.

Rasmussen, L.: Den dag, Angmagssalik næsten blæste I havet, Vejret, Dan. Meteorol. Soc., 2, 3-14, 1989.

Rignot, E. and Kanagaratnam, P.: Changes in the velocity structure of the Greenland ice sheet, 20 Science, 311, 986-990, 2006.

Shuman, C. A., Steffen, K., Box, J. E., and Stearns, C. R.: A dozen years of temperature observations at the summit: central Greenland automatic weather stations 1987-99, J. Appl. Meteorol., 40, 741-752, 2001.

Smeets, C. J. P. P. and Van den Broeke, M. R.: The parameterisation of scalar transfer over rough ice, Bound.-Lay. Meteorol., 128, 339-355, 2008.

Stearns, L. A. and Hamilton, G. S.: Rapid volume loss from two East Greenland outlet glaciers quantified using repeat stereo satellite imagery, Geophys. Res. Lett., 34, L05503, 2007.

Tedesco, M., Serreze, M., and Fettweis, X.: Diagnosing the extreme surface melt event over southwestern Greenland in 2007, The Cryosphere, 2, 159-166, 2008.

30 Van As, D., Van den Broeke, M. R., and Helsen, M. M.: Strong-wind events and their impact on the near-surface climate at Kohnen Station on the Antarctic Plateau, Antarct. Sci., 19, 507-519, 2007.

Van As, D., Van den Broeke, M., Reijmer, C., and Van de Wal, R.: The summer surface energy

\section{South Greenland climatology and ablation \\ D. van As et al.}

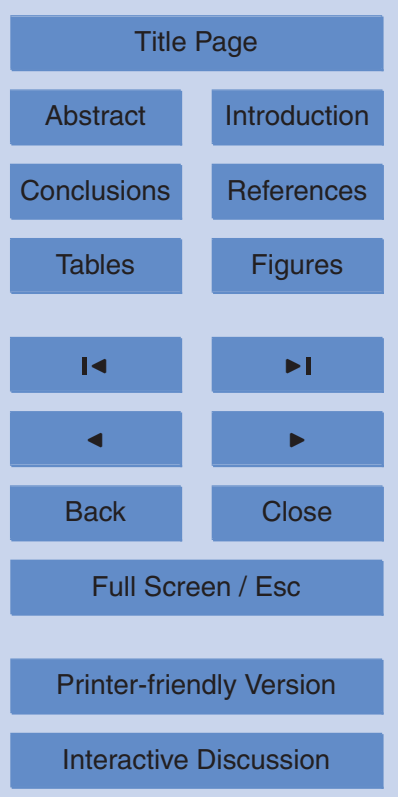


balance of the high Antarctic plateau, Bound.-Lay. Meteorol., 115, 289-317, 2005.

Van de Wal, R. S. W., Boot, W., Van den Broeke, M. R., Smeets, C. J. P. P., Reijmer, C. H., Donker, J. J. A., and Oerlemans, J.: Large and rapid melt-induced velocity changes in the ablation zone of the Greenland Ice Sheet, Science, 321, 111-113, 2008.

5 Van de Wal, R. S. W., Greuell, W., Van den Broeke, M. R., Reijmer, C. H., and Oerlemans, J.: Surface mass-balance observations and automatic weather station data along a transect near Kangerlussuaq, West Greenland, Ann. Glaciol., 42, 311-316, 2005.

Van den Broeke, M., Smeets, P., Ettema, J., and Kuipers Munneke, P.: Surface radiation balance in the ablation zone of the west Greenland ice sheet, J. Geophys. Res., 13, D13105, doi:10.1029/2007JD009283, 2008a.

Van den Broeke, M., Smeets, P., Ettema, J., Van der Veen, C., Van de Wal, R., and Oerlemans, J.: Partitioning of melt energy and meltwater fluxes in the ablation zone of the west Greenland Ice Sheet, The Cryosphere, 2, 179-189, 2008b.

Van den Broeke, M., Van As, D., Reijmer, C., and Van de Wal, R.: Assessing and improving the quality of unattended radiation observations in Antarctica, J. Atmos. Ocean. Tech., 21, 1417-1431, 2004.

Wang, L., Sharp, M., Rivard, B., and Steffen, K.: Melt season duration and ice layer formation on the Greenland ice sheet, 2000-2004, J. Geophys. Res., 112, F04013, 2007.

\section{South Greenland climatology and ablation \\ D. van As et al.}

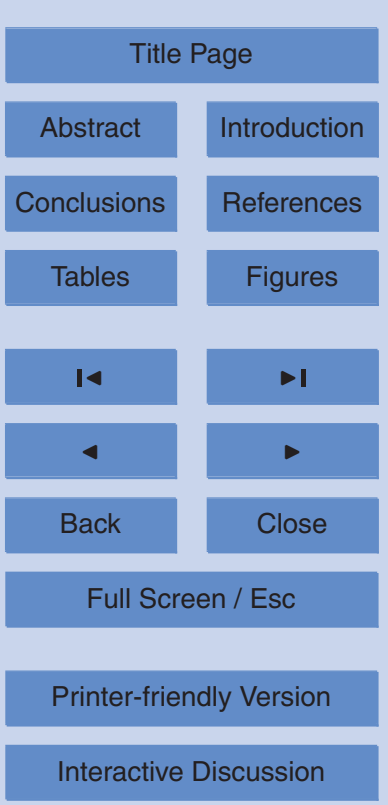


3, 117-158, 2009

Table 1. Initial location and operational period of the AWSs

\begin{tabular}{lllrl}
\hline Name & Latitude & Longitude & Elevation asl. & Operational period \\
\hline St71 & $61^{\circ} 01.52^{\prime} \mathrm{N}^{\mathrm{a}}$ & $46^{\circ} 52.27^{\prime} \mathrm{W}^{\mathrm{a}}$ & $\sim 300 \mathrm{~m}$ & May 2001 to Aug 2007 \\
St72 & $61^{\circ} 18.91^{\prime} \mathrm{N}$ & $46^{\circ} 35.14^{\prime} \mathrm{W}$ & $\sim 1250 \mathrm{~m}$ & May 2001 to May 2003 \\
Nuuk1 & $64^{\circ} 38.20^{\prime} \mathrm{N}$ & $50^{\circ} 00.76^{\prime} \mathrm{W}$ & $\sim 100 \mathrm{~m}$ & Jun 2003 to Oct 2003 \\
Nuuk2 & $64^{\circ} 44.17^{\prime} \mathrm{N}$ & $49^{\circ} 29.55^{\prime} \mathrm{W}$ & $\sim 900 \mathrm{~m}$ & Jun 2003 to Jun 2006 \\
Tas1 & $65^{\circ} 42.21^{\prime} \mathrm{N}$ & $38^{\circ} 51.92^{\prime} \mathrm{W}$ & $\sim 590 \mathrm{~m}$ & May 2004 to Aug 2007 \\
Tas3 & $65^{\circ} 38.50^{\prime} \mathrm{N}$ & $38^{\circ} 53.89^{\prime} \mathrm{W}$ & $\sim 280 \mathrm{~m}$ & Jun 2006 to Aug 2007 \\
\hline
\end{tabular}

\section{South Greenland climatology and ablation \\ D. van As et al.}

a - Moved to these coordinates from a position $2.7 \mathrm{~km}$ further west in May 2004.

$\mathrm{b}$ - AWS was lost in 2004. All data were obtained from summertime transmissions.

\section{Full Screen / Esc}

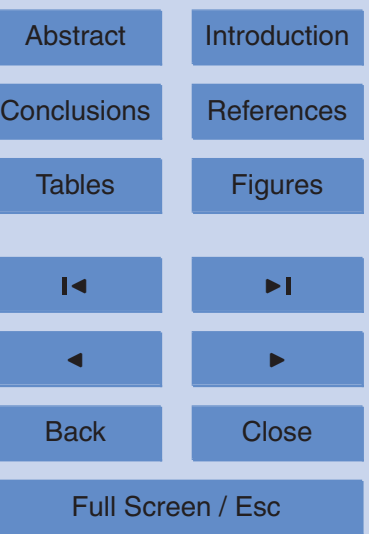

Interactive Discussion 
3, 117-158, 2009

Table 2. List of sensors and their accuracies as reported in the sensor manuals on St71, Nuuk2, and Tas1.

\begin{tabular}{lll}
\hline Parameter & Sensor & Accuracy \\
\hline Air temperature & Vector T302 aspirated & $0.1^{\circ} \mathrm{C}$ \\
Relative humidity & Vaisala HMP45C/D & $2 \%$ for $\mathrm{RH}<90 \%$ at $20^{\circ} \mathrm{C}$ \\
& & $3 \%$ for $\mathrm{RH}>90 \%$ at $20^{\circ} \mathrm{C}$ \\
Wind speed & Aanderaa 2740 & $2 \%$ or $0.2 \mathrm{~ms}^{-1}$ \\
& Young 05103 (Tas1) & $0.3 \mathrm{~ms}^{-1}$ \\
Wind direction & Aanderaa 2053 & $<5^{\circ}$ \\
& Young 05103 (Tas1) & $3^{\circ}$ \\
Shortwave radiation (in\&out) & Kipp \& Zonen CM7 ${ }^{\circ}$ & $<8 \%$ for hourly totals \\
& & $<5 \%$ for daily totals \\
Longwave radiation (in) & Eppley PIR & Not specified \\
Surface height & Campbell Sci. SR50 & $0.01 \mathrm{~m}$ or $0.4 \%$ \\
Ice ablation & Ørum \& Jensen NT1400 & Unknown in this application \\
AWS inclination & HL-Planar NS-25/E2 & $0.6 \%$ \\
AWS orientation & Aanderaa 2053 & $<5^{\circ}$ \\
& Pewatron 6100 (Tas1) & unknown \\
\hline
\end{tabular}

\section{South Greenland climatology and ablation \\ D. van As et al.}

Title Page

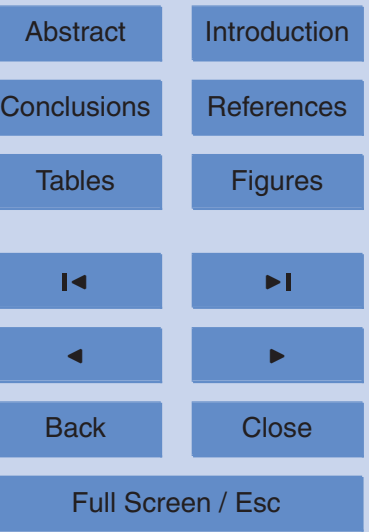

b - Larger uncertainty at Tas 1 due to lacking sensor housing temperatures. 


\section{TCD}

3, 117-158, 2009

\section{South Greenland climatology and ablation \\ D. van As et al.}

Table 3. Mean surface energy fluxes in $\mathrm{Wm}^{-2}$ at St71, Nuuk2, and Tas1 in mid-summer (July and August).

\begin{tabular}{lrrrrrr}
\hline & St71 & \% of M & Nuuk2 & \% of M & Tas1 & \% of M \\
\hline$S R_{\text {net }}$ & 147.5 & 86 & 132.0 & 101 & 119.4 & 78 \\
$L R_{\text {net }}$ & -14.9 & -9 & -35.2 & -27 & -16.7 & -11 \\
$S H$ & 34.4 & 20 & 37.5 & 29 & 48.9 & 32 \\
$L H$ & 3.9 & 2 & -4.1 & -3 & 1.1 & 0.7 \\
$S S H$ & 0.5 & 0.3 & 0.7 & 0.5 & 0.4 & 0.2 \\
$M$ & 171.4 & & 130.9 & & 153.1 &
\end{tabular}

Title Page

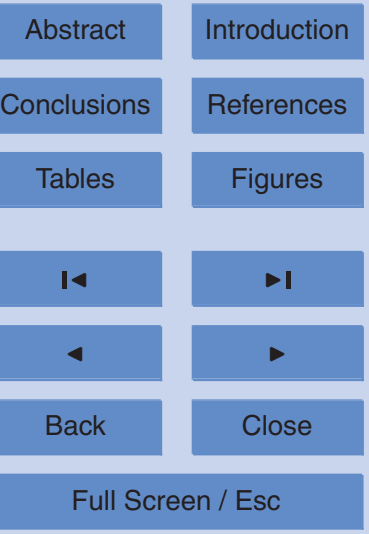

Printer-friendly Version

Interactive Discussion 
3, 117-158, 2009

Table 4. Calculated ablation and sensitivity to inaccuracies in observed and chosen parameters (in meters of ice).

\section{South Greenland climatology and ablation \\ D. van As et al.}

\begin{tabular}{lccccc}
\hline Parameter & Change & St71 2001 & St712003 & Nuuk2 2003 & Tas1 2004 \\
\hline Main run & & 4.21 & 4.55 & $3.36^{\mathrm{a}}$ & 3.59 \\
Net shortwave radiation & $+10 \%$ & +0.34 & +0.39 & +0.35 & +0.28 \\
Incoming longwave radiation & $+5 \%$ & +0.46 & +0.44 & +0.34 & +0.33 \\
Air temperature & $+0.5^{\circ} \mathrm{C}$ & +0.12 & +0.14 & +0.16 & +0.20 \\
Relative humidity & $-5 \% \%^{\mathrm{b}}$ & -0.14 & -0.14 & -0.14 & -0.17 \\
Wind speed & $+0.5 \mathrm{~ms}^{-1}$ & +0.35 & +0.28 & +0.14 & +0.20 \\
Air pressure & $+20 \mathrm{hPa}$ & +0.02 & +0.02 & +0.02 & +0.02 \\
Surface roughness length for momentum & $\times 5$ & +0.46 & +0.40 & +0.22 & +0.35 \\
Initial ice temperature & $-5^{\circ} \mathrm{C}$ & -0.11 & -0.11 & -0.09 & -0.09 \\
Start date ice melt & +10 days & -0.40 & -0.70 & -0.34 & -0.54 \\
\hline
\end{tabular}

Title Page

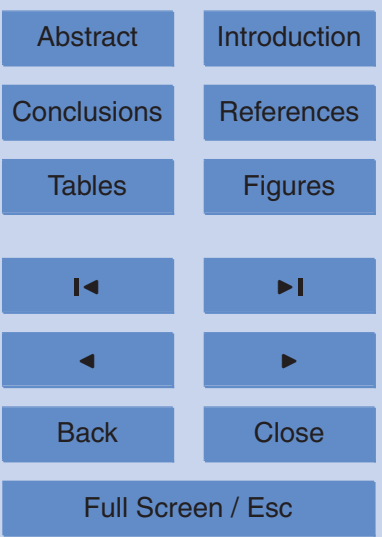

Printer-friendly Version

Interactive Discussion 


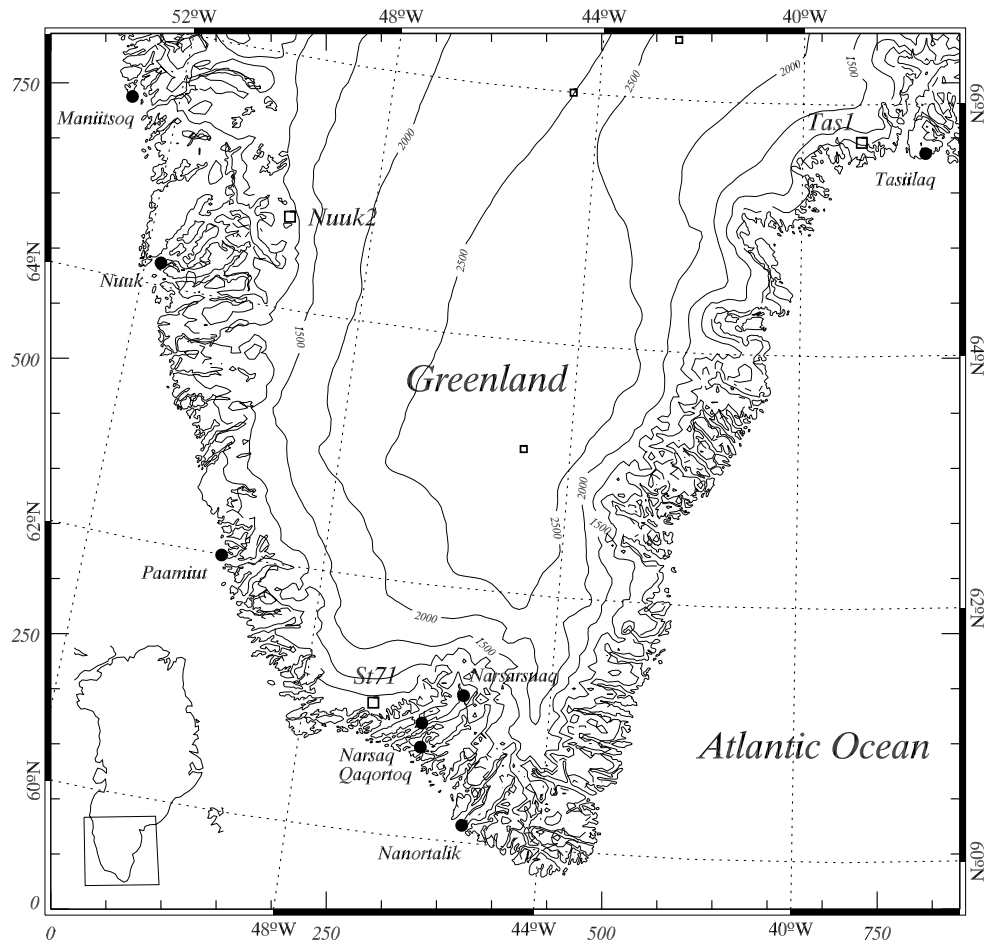

Fig. 1. Map of South Greenland, showing the positions of the automatic weather stations St71, Nuuk2, and Tas1. Small squares give the locations of GC-Net stations. Elevation lines give surface height above sea level in meters (Bamber et al., 2001). Distance in kilometres is given along the axes.
TCD

3, 117-158, 2009

\section{South Greenland climatology and ablation \\ D. van As et al.}

Title Page

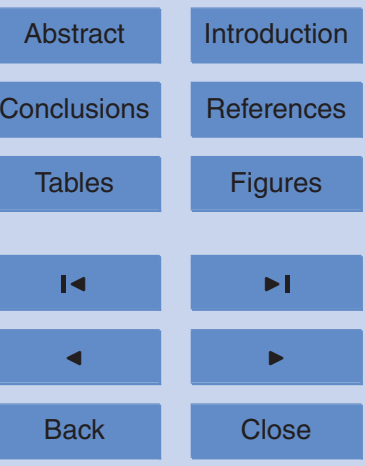

Full Screen / Esc

Printer-friendly Version

Interactive Discussion 


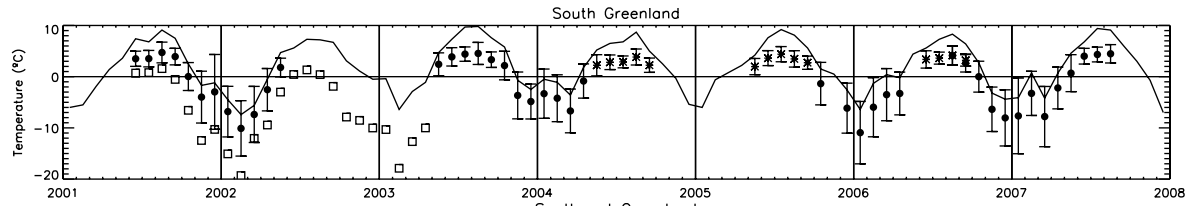

\section{South Greenland climatology and ablation \\ D. van As et al.}

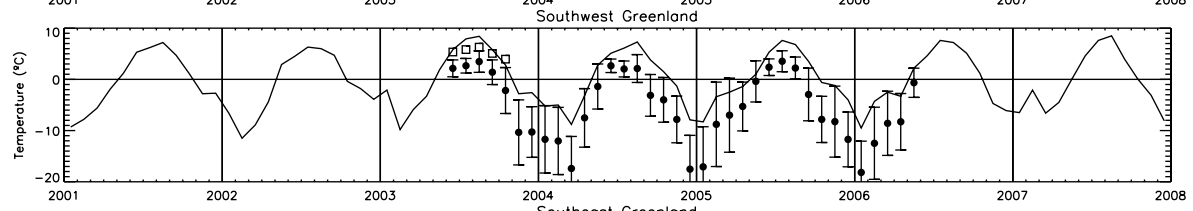

Title Page

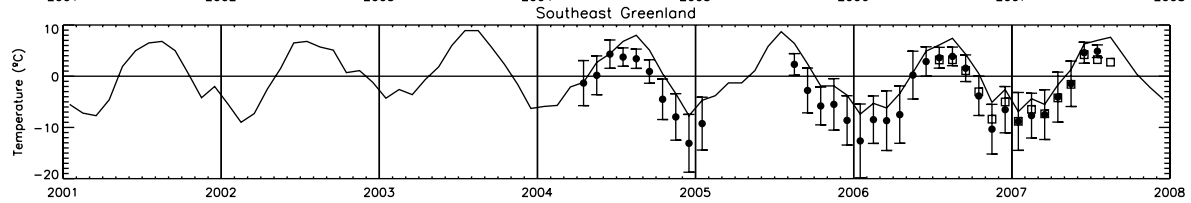

Fig. 2. Observed monthly-mean near-surface temperatures at St71 (top), Nuuk2 (middle), and Tas1 (bottom). Dots signify means of hourly values; asterisks indicate that means were calculated from transmitted data every six hours. Squares show data from the neighbouring AWSs listed in Table 1. Solid lines show data from the nearest DMI land station (resp. Qaqortoq, Nuuk, and Tasiilaq).

\section{4}

4

Back
$>1$

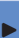

Close

\section{Full Screen / Esc}

Printer-friendly Version

Interactive Discussion 


\section{TCD}

3, 117-158, 2009
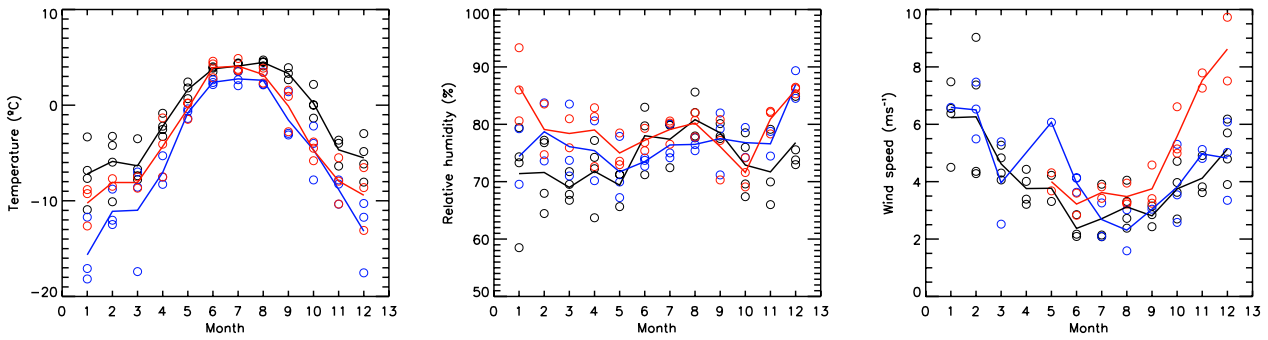

\section{South Greenland climatology and ablation \\ D. van As et al.}

Fig. 3. Monthly-mean values of near-surface temperature (left), relative humidity (middle), and wind speed (right) for St71 (black), Nuuk2 (blue), and Tas1 (red). Solid lines give multi-year averages.

Title Page

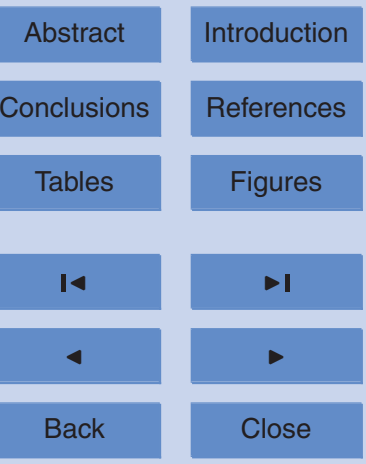

Full Screen / Esc

Printer-friendly Version

Interactive Discussion 


\section{TCD}

3, 117-158, 2009
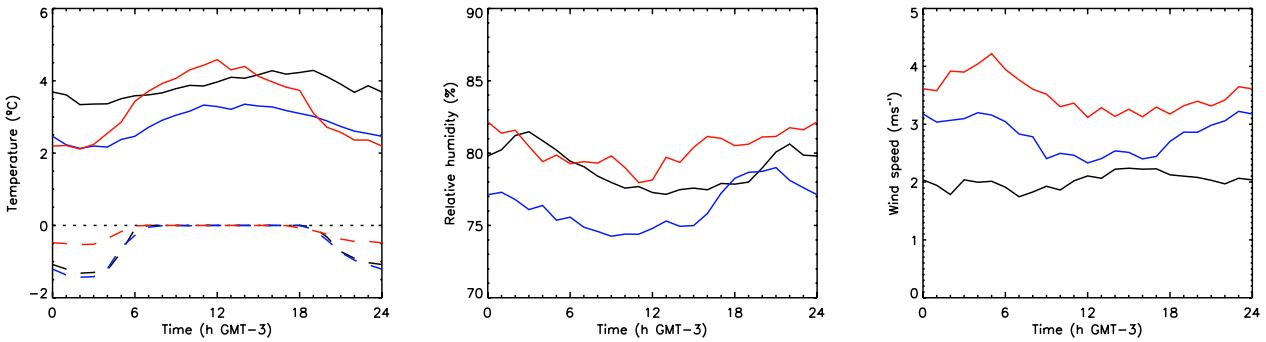

\section{South Greenland climatology and ablation \\ D. van As et al.}

Fig. 4. Mean summer daily cycles of temperature, relative humidity, and wind speed calculated at two meters (solid lines) and at the surface (dashed lines) for St71 (black), Nuuk2 (blue), and Tas1 (red).

Title Page

\section{Abstract}

Introduction

Conclusions

References

Tables

Figures

14

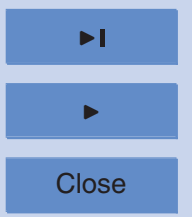

Back 
3, 117-158, 2009

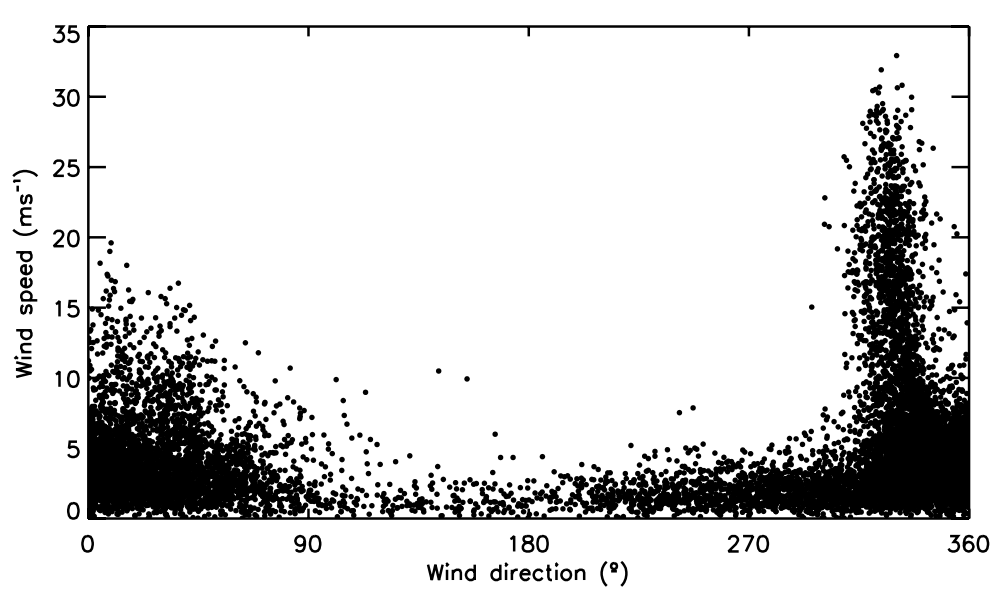

\section{South Greenland climatology and ablation \\ D. van As et al.}

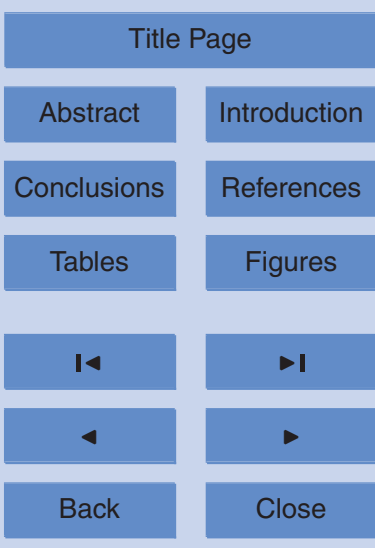

Full Screen / Esc

Printer-friendly Version

Interactive Discussion 
3, 117-158, 2009

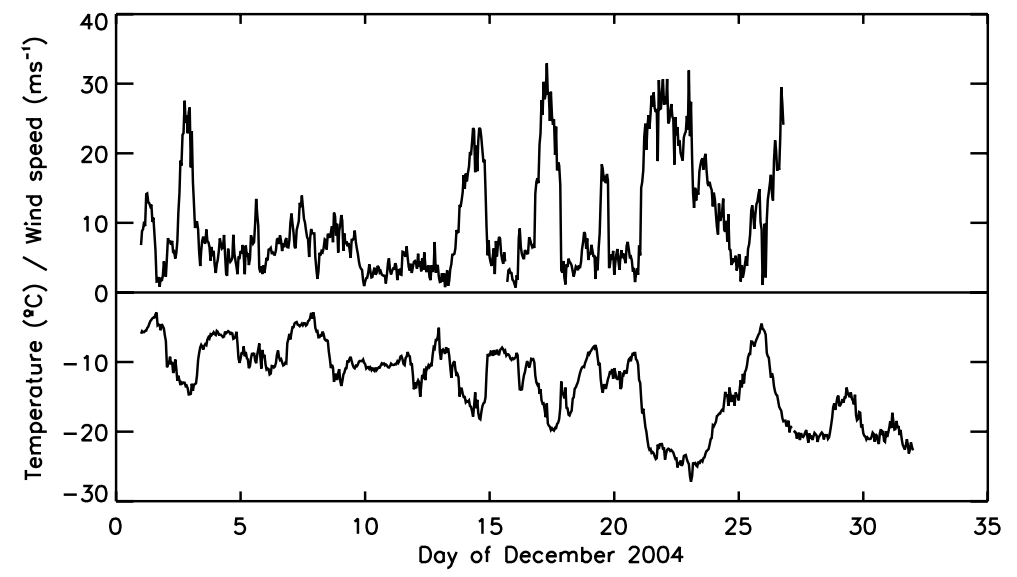

\section{South Greenland climatology and ablation \\ D. van As et al.}

Title Page

Fig. 6. Hourly values of temperature (negative values) and wind speed (positive values) at Tas 1 for December 2004. 


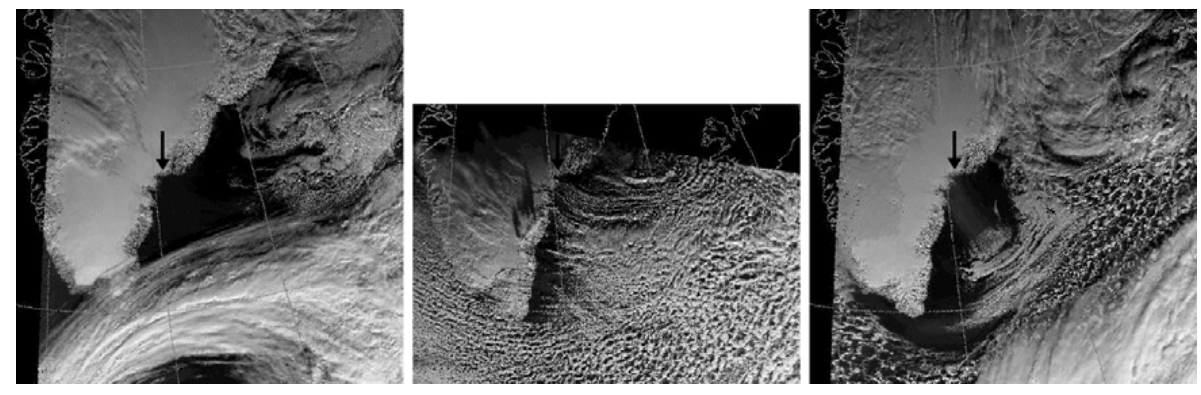

Fig. 7. MODIS images of South Greenland taken around midday on 30 October 2004 (left), 27 December 2004 (middle), and 5 November 2006 (right). The arrow gives the position of AWS Tas1.

\section{South Greenland climatology and ablation \\ D. van As et al.}

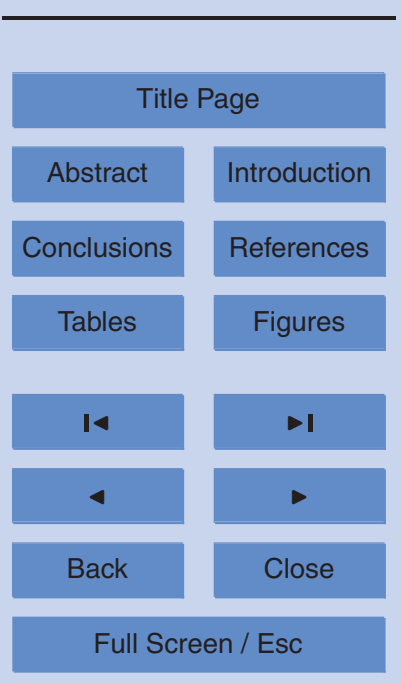

Printer-friendly Version

Interactive Discussion 
3, 117-158, 2009
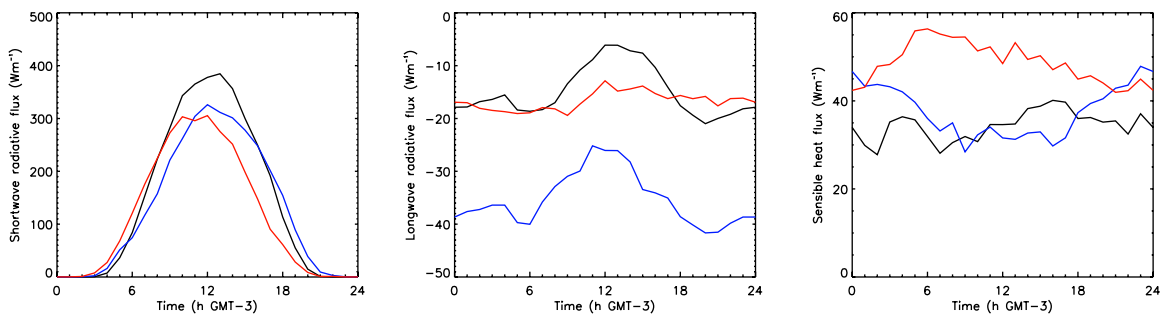

\section{South Greenland climatology and ablation \\ D. van As et al.}
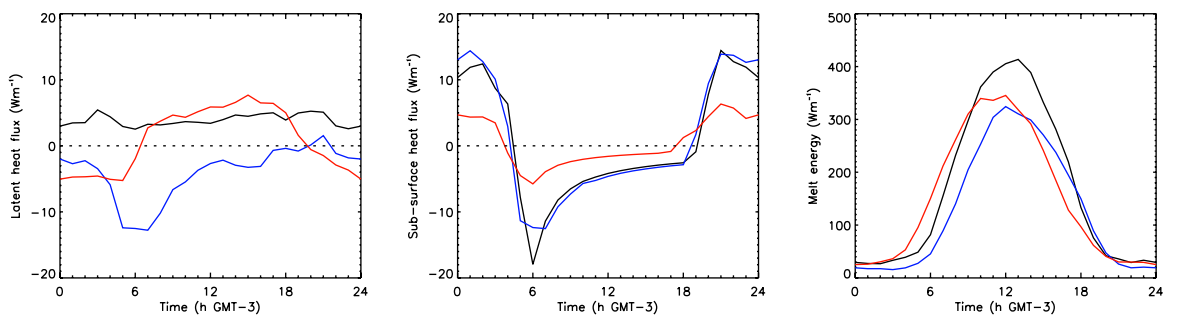

Title Page

Fig. 8. Mean summer daily cycles of net short-/longwave radiation, sensible/latent/sub-surface heat fluxes, and energy used for ice melt at St71 (black), Nuuk2 (blue), and Tas1 (red).

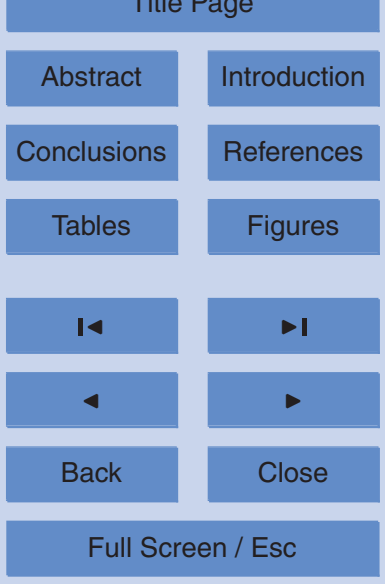

Printer-friendly Version

Interactive Discussion 


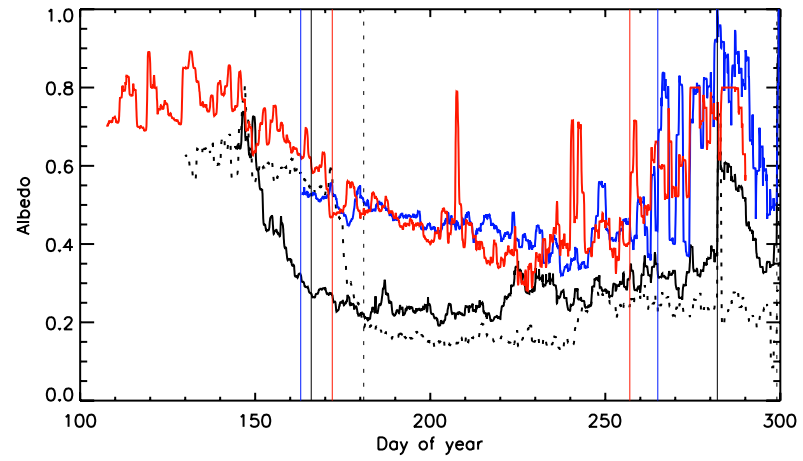

\section{3, 117-158, 2009}

\section{South Greenland climatology and ablation \\ D. van As et al.}

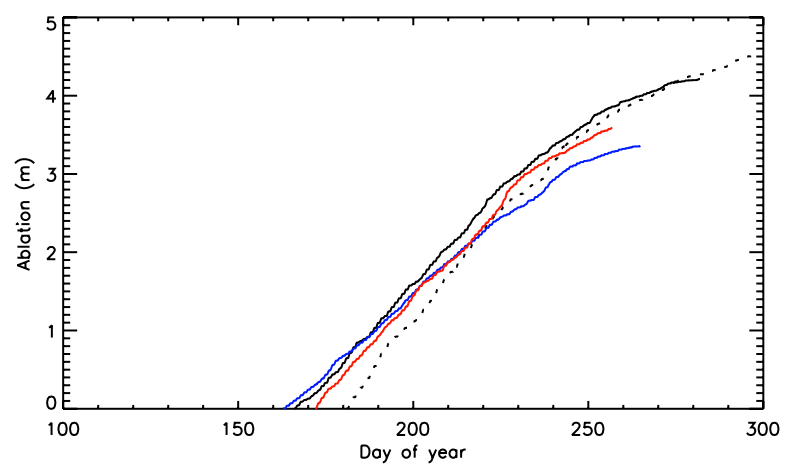

Title Page

Abstract

Conclusions

Tables
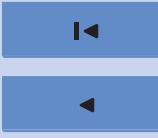

Back
Introduction

References

Figures

$>1$

$>$

Close

\section{Full Screen / Esc}

Printer-friendly Version St71 (black), Nuuk2 (blue), and Tas1 (red). The solid black line gives 2001 data for St71, the dotted line gives 2003 data. Vertical lines denote the estimated bounds of the period with a

Interactive Discussion 


\section{TCD}

3, 117-158, 2009

\section{South Greenland climatology and ablation \\ D. van As et al.}

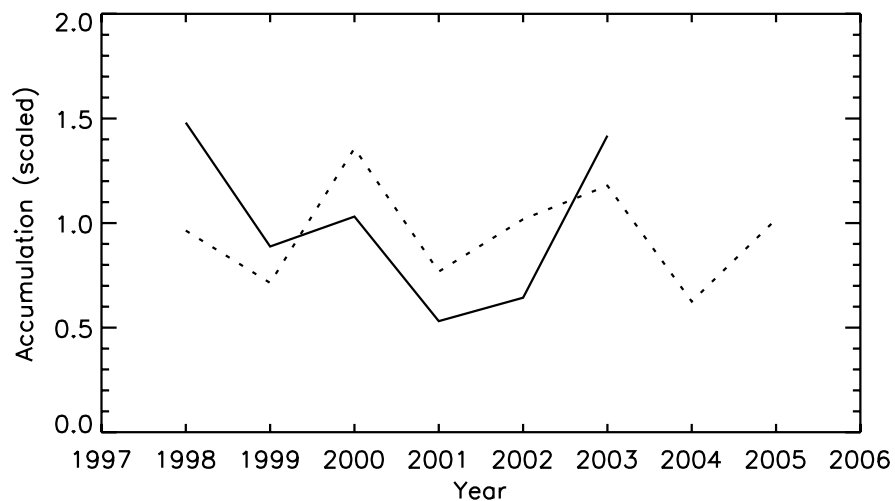

Fig. 10. Preceding winter (November-April) accumulation at the saddle point (dotted line) and southern dome (solid line) of the Greenland Ice Sheet, scaled to the 1998-2003 mean.

Title Page

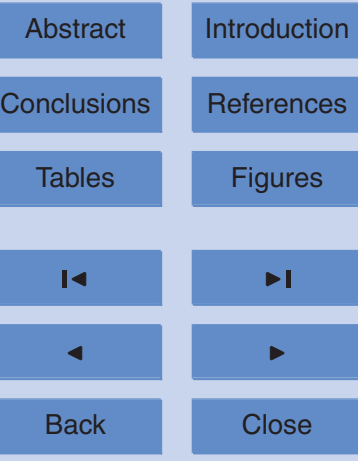

Full Screen / Esc

Printer-friendly Version

Interactive Discussion 